\title{
Müşterilerin Mobil Ödeme Hizmetleri Kullanım Davranışlarını ve Kullanıcı Tatminini Etkileyen Faktörlerin İncelenmesi
}

\author{
Esma DURUKAL ${ }^{1}$, Kevser ARMAN² \\ Özet
}

Geleneksel ödeme yöntemlerine alternatif bir ödeme aracı olan mobil ödeme hizmetleri kullanıcılara sağladığı sayısız avantaja rağmen halâ dünyada yaygın olarak kullanılmamaktadır. Son yıllarda mobil teknolojilere artan ilgi mobil ödeme hizmetleri kavramını gündeme getirmektedir. Bu çalışmanın amacı tüketicilerin mobil ödeme hizmetleri kullanımını öngörebilecek ana faktörlerin test edilmesinin yanı sıra böyle bir sistemi kullanmanın müşteri memnuniyetine sağlayabileceği katkıyı araştırmaktır. Çalışmada ele alınan IS Success modeli mobil ödeme hizmetlerinin başarısını ölçmeyi sağlarken, UTAUT ise mobil ödeme hizmetlerinin başarılı olmasına yol açan faktörleri ortaya koymaktadır. Araştırmada 246 kullanıcıya anket yapılmış, araştırma sonuçları yapısal eşitlik modeli LISREL programı ile analiz edilmiştir.

Anahtar kelimeler: Mobil ödeme, UTAUT modeli, IS success modeli, müşteri tatmini Jel Kodu: C01, C23, K12

\section{Examination of Factors Affecting the Customers' Mobile Payment Services Usage Behavior and User Satisfaction}

\begin{abstract}
Mobile payment services, which are an alternative payment method to traditional payment methods, are still not widely used in the world despite the numerous advantages that they provide to users. The increasing interest in mobile technologies in recent years brings the concept of mobile payment services to the agenda. The aim of this study is to test the main factors that can predict the use of mobile payment services by consumers, as well as to investigate the contribution that using such a system can provide to customer satisfaction. While the IS Success model discussed in the study allows to measure the success of mobile payment services, UTAUT reveals the factors leading to the success of mobile payment services. In the research, 246 users were surveyed and the results of the research were analyzed with the structural equation model LISREL program.
\end{abstract}

Keywords: Mobile payment, UTAUT, IS success, cusstomer satisfaction

Jel Codes: C01, C23, K12

ATIF ÖNERİí (APA): Durukal, E., Arman, K. (2021). Müşterilerin Mobil Ödeme Hizmetleri Kullanım Davranışlarını ve Kullanıcı Tatminini Etkileyen Faktörlerin İncelenmesi. İzmir İktisat Dergisi. 36(1). 171-190.

Doi: $10.24988 /$ ije. 202136112

${ }^{1}$ Dr. Öğr. Üyesi, Aydın Adnan Menderes Üniversitesi, İktisadi ve İdari Bilimler Fakültesi, Nazilli /AYDIN,

EMAIL: eacayip@adu.edu.tr ORCID:0000-0001-8684-6311

2 Araş. Gör., Pamukkale Üniversitesi, İktisadi ve İdari Bilimler Fakültesi, Pamukkale / DENİZL̇,

EMAIL: karman@pau.edu.tr ORCID:0000-0002-4400-5976 


\section{GíRiş}

Akıllı telefonların artan kullanımı ile teknolojik gelişme, diğer işlevlerin yanı sıra cep telefonu aracılığıyla satın alma ve ödeme işlemlerini kolaylaştırmaktadır. $\mathrm{Bu}$ fenomen dünya çapında meydana gelmekte ve bireylere günlük aktivitelerini gerçekleştirirken daha fazla esneklik ve kolaylık sağlamaktadır. Teknolojik yeniliklerin insanların yaşamlarındaki etkilerini anlamak, birçok sosyal bilim araștırmacısının zamanla ilgisini uyaran bir şeydir. Bu yenilikler bireysel hareketliliğe bağlı olduğunda, sosyal ve profesyonel yaşama fayda sağlamaktadır (Abrahão vd., 2016: 221). Son yıllarda literatür mobil alışveriş, mobil seyahat hizmeti, çevrimiçi ve çevrimdışı tüketim vb. mobil ticaret uygulamalarının popülerliğine tanıklık etmektedir. Mobil ticaretin refahı, mobil ödeme (m-ödeme) tüketici kabulüne büyük ölçüde bağlıdır ve bir cep telefonu veya kişisel dijital asistan gibi mobil terminaller aracılığıyla yürütülmektedir (Yang vd., 2014: 253). Mobil teknoloji günümüzün günlük yaşamında giderek yaygınlaşmaktadır. Bununla birlikte, teknolojik olarak gelişmiş çözümler mevcut olmasına rağmen, mobil ödeme şaşırtıcı bir şekilde sık kullanılan mobil hizmetler arasında değildir. Görünüșe göre, tüketiciler arasında mobil ödeme hizmetlerinin kabulü hala eksiktir (Schierz vd., 2010: 209). Mobil internet gibi mobil telekomünikasyon teknolojilerindeki hızlı ilerlemeler nedeniyle, müşterilerin alışveriş ve ödeme davranışlarını önemli ölçüde değiştiren farklı türde mobil teknolojiler ve uygulamalar ortaya çıkmıștır (Khalilzadeh vd., 2017: 460). Günlük yaşantımızda önemli bir yer teşkil eden ödeme işlemleri çeşitli şekillerde gerçekleşebilmektedir. Her geçen gün dijitalleşen günümüz dünyasında ise mobil ödemeler bireylerin ödeme işlemlerini hızlı, kolay ve güvenli bir şekilde gerçekleştirmesine yardımcı olmaktadır. Yakından mobil ödemeler ve uzaktan mobil ödemeler, mobil ödeme yöntemlerinin iki temel grubu olarak düşünülebilir. Yakından mobil ödemeler (örneğin: NFC, Bluetooth, QR, mobil cüzdan vb.) bir satış noktası (POS) cihazı ve bir cep telefonunun ödeme işlemi için aynı yerde birlikte olmasını gerektiren yöntemdir; uzaktan mobil ödemeler ise (örneğin: SMS, Mobil Faturalandırma, WAP vb.) mobil ödeme cihazının ve satıcının aynı yerde olmasını gerektirmemektedir (Örs, 2018: 2). Sürekli olarak popülerlik kazanan böyle bir teknoloji Yakın Alan İletişimi (NFC) tabanlı mobil ödeme (MP) sistemleridir. NFC teknolojisinin yardımıyla, NFC etiketleriyle donatılmış akıllı telefonlar gibi mobil cihazlar, tüketicilerin mobil cihazlarını NFC özellikli bir ödeme terminaline yönlendirerek satın alma işlemlerini kolayca tamamlayabilecekleri sanal bir cüzdan gibi davranma yeteneğine sahiptir. NFC sistemlerinin avantajları arasında düşük güç tüketimi, kullanım kolaylığı ve basit iletişim kurulumu yer almaktadır (Khalilzadeh vd., 2017: 460). Türkiye'de mobil ödemeler özellikle genç nüfus tarafından kullanılan bir ödeme yöntemi olarak işlem hacmini her geçen gün arttırmaya devam etmektedir. BKM tarafından yapılan araștırma sonucunda Türkiye'de online alışveriş yapan her üç kişiden biri mobil alışverişi tercih etmektedir (http://www.tubisad.org.tr/). Çoğunlukla mobil ödemeler aracılığı ile gerçekleşen eticaret hacminin her geçen gün büyümesi ise mobil ödeme hizmetlerinin başarısı ile yakından ilişkilidir. Bir mobil ödeme hizmetinin başarılı bir şekilde gerçekleşmesi için genel gereksinimlerden bazıları şunlardır: basitlik ve kullanılabilirlik, evrensellik, birlikte çalışabilirlik, güvenlik, hız, maliyet, yerel pazarı anlama, sınırları aşan ödemeler, eski yaklaşımların bütünleşmesi ve güven ve gizliliktir (Karnouskos ve Fokus, 2004: 46).

Son on yllda mobil ödemelerin kabulü akademisyenler ve uygulayıcılar tarafından dikkat çekmektedir. Apple Pay, Google Cüzdan ve PayPal, cep telefonunu kullanarak alışveriş yapmak için kullanılan teknolojilerden sadece birkaçıdır. Ayrıca, perakendeciler, bu teknolojinin satın alma niyeti üzerindeki etkisi nedeniyle mobil ödemeyi keşfetme ihtiyacının farkına varmışlardır. Mobil ödeme hizmetlerinin çok azı pazarda başarılı olmuş 
veya kritik bir kullanıcı kitlesine ulaşmıştır (Molina-Castillo vd., 2020: 2). Bununla birlikte, mobil ödemeler giderek geleneksel ödeme sistemlerine uygulanabilir bir alternatif olarak kabul edildiğinden büyük ilgi görmekle birlikte, bu teknolojinin muazzam potansiyeline rağmen, kullanım beklenenden daha yavaş olmaktadır. Aslında, nakit ödeme halâ birçok ekonomide en çok tercih edilen ödeme yöntemi olup, bazı gelişmekte olan ülkelerdeki tüm ödemelerin \%90'ına karşıllı gelmektedir. Bu nedenle, mobil ödeme kabulünün belirleyicilerini anlamak ve araștırmak giderek daha önemli hale gelmektedir (Verkijika, 2020: 1). Mobil ödemelerle ilgili araştırmalar henüz başlangıç aşamasındadır ancak mobil ödemelerin kabulünü etkileyen faktörlerin daha iyi anlaşılmasına ihtiyaç vardır (Thakur ve Srivastava, 2014: 370). Mobil ödeme sistemlerine ilișkin daha önceki çalışmalar, teorik bir çerçeve olarak teknoloji kabul modelini (TAM) kullanarak, diğer sistem türlerinin teknolojinin benimsenmesini analiz etmeye odaklanmıștır. Bununla birlikte, her bir ödeme sisteminin benimsenmesini etkileyen belirli özellikleri vardır (örneğin, algılanan fayda, algilanan risk gibi boyutlar) (Kalinic vd., 2019: 143). Ayrica, daha önce yapılan araştırmalara göre, dünyada ve Türkiye'de henüz gelişme aşamasında bir hizmet olan mobil ödeme hizmetleri ile ilgili ortak kanıya varılan bir yöntem ya da teknolojinin olmadı̆̆ belirtilmektedir (www.btk.gov.tr). Bu bağlamda tüketicilerin mobil ödeme hizmetlerini benimsemesi ve kullanımında etkili olan faktörlerin ortaya konulması gerekmektedir. $\mathrm{Bu}$ çalışmanın amacı, tüketicilerin mobil ödeme hizmetleri kullanımını öngörebilecek ana faktörlerin test edilmesinin yanı sıra böyle bir sistemin kullanılmasının müşteri memnuniyetine sağlayabileceği katkının araştırılmasıdır.

\section{KAVRAMSAL ÇERÇEVE}

\subsection{Mobil ödeme hizmetleri}

Mobil ödeme sistemlerinin tüketicilere sağladığı potansiyel faydalara rağmen dünya çapında benimsenmesi oldukça yavaş olmaktadır. Nakit ödemelerin tüm ödemelerin \%90'ından fazlasını oluşturduğu gelişmekte olan ülkelerde, nakit ödemenin kral olmasına bakılmaksızın mobil ödemelerin önümüzdeki birkaç yll içinde benzeri görülmemiş bir büyüme göreceğine dair tahminler bulunmaktadır. Bununla birlikte tüketicileri, diğer iyi bilinen ödeme sistemlerine alternatif olarak mobil ödeme sistemlerini kullanmaya ikna etmek için dünyanın dört bir yanındaki birçok araştırmacl, mobil ödeme sistemlerinin benimsenmesi ve kullanımlarının temel belirleyicilerini anlamak üzerine araștırma yapmaktadır (Verkijika, 2020: 1). 1990'ların sonunda ortaya çıkan mobil ödeme hizmetleri, nakit ihtiyacını ortadan kaldırır veya azaltır, kolaylık ve hız sunar ve bilgilerin güvenli bir şekilde aktarılmasını sağlamaktadır. Mobil ödeme hizmetleri, herhangi bir ekonomik işlemi gerçekleştirmek için mobil internete sahip dijital cihazlar kullanan ticari veya bireysel faaliyetleri ifade etmektedir (Verma vd., 2020: 3). Mobil ödeme, tüketici satın alma süreçlerini ve sağlayıcıların iş modellerini dönüştüren devrim niteliğinde bir teknoloji olarak kabul edilir. Bazı yazarlar, mobil ödemenin bir mobil iletişim platformunda bir mobil cihaz kullanarak mal veya hizmet satın almayı içerdiği fikrini kabul eder. Bu nedenle, mobil ödemenin tanımını iki ana unsur oluşturmaktadır: birincisi, ödemeyi gerçekleștirecek mobil teknoloji veya hizmeti kapsaması diğeri ise ödemenin gerçekleșmesi için gereken ağ veya platform'dur (MolinaCastillo vd., 2020: 2).

Tüketicilerin bakış açısından, mobil ödeme hizmetlerinin avantajları arasında kolaylık, yer ve zamandan bağımsız satın alımlar, kişiden kişiye para transferi, bilet işlemleri ve sadakat programları yer almaktadır. Ayrıca mobil ödeme hizmetlerinin perakendecilere sağladığı faydalar; hizmetlerin daha hızlı, daha düşük işlem maliyetli ve nakit işlem sayısındaki düşüşü kapsamaktadır. Mobil ödeme hizmetlerinin tüm bu faydaları, onu elektronik ödeme hizmetleri evriminin bir sonraki adımı haline getirir ve büyümek için büyük bir potansiyele sahiptir. $\mathrm{Bu}$ nedenlerden dolayı, 
uygulayıcılar ve akademisyenler bu yeni yeniliği araștırmaya başlamışlardır ve mobil ödeme hizmetleri çalışmalarının sayısı muazzam bir şekilde artmaktadır (Verma vd., 2020: 3). Bilgi, eğlence ve işlem izinlerine erişim (bilet rezervasyonu, takip emirleri, bankacılı hizmetleri ve kayıtların doğrulanması) gibi bugün sunulan hizmetler arasında "mobil ödeme" (veya m-ödeme) adı verilen bir eğilim var olmaktadır. Bu süreç, mobil cihaz üzerinden nakit ya da bankacılık kurumlarının katılımı gerekmeksizin yapılan değerlerin satın alınması, ödenmesi veya devredilmesini amaçlamaktadır. Cep telefonları veya akıllı telefonlar gibi mobil cihazlar, ödemelerin başlatılabileceği, etkinleştirilebileceği ve /veya onaylanabileceği bir araç olarak işlev görmektedir (Abrahão vd., 2016: 221). Hongxia ve arkadaşları (2011)'na göre mobil ödemeler, cep telefonlarl, kişisel dijital asistanlar (PDA), radyo frekansı (RFID) cihazları veya yakın alan iletişimi (NFC) tabanlı cihazlar gibi mobil cihazları kullanarak ödeme yapmayl ifade etmektedir. Mobil ödemeler, mobil iletişim araçlarını (örneğin akıllı telefonlar tabletler vb.) kullanarak ödemelerin mobil ağlar veya kablosuz iletişim teknolojileri üzerinden alıcıya aktarıldığı, finansal bir ișlemi başlatma, yetkilendirme ve tamamlama becerisini sağlamak için uygulanan hizmetlerdir (Chandra vd., 2010: 563). Cihaz ve ödeme hizmeti sağlayıcısına bakılmaksızın, mobil ödeme cihazları bankalarına kayıtlıdır ve böylece mobil cihazdaki birkaç tuşa basılarak ödeme yapan banka (veya kredi kartı hesabı), alacaklının banka hesabına yüksek güvenlikli fon aktarımı sağlamaktadır (Thakur ve Srivastava, 2014: 370). Diğer bir deyişle mobil ödemeler, kablosuz ve diğer iletişim teknolojilerinden yararlanarak bir mobil cihazla (dijital asistan, akıllı telefon vb.) mallar, hizmetler ve faturalar için yapılan ödemelerdir (Dahlberg vd., 2008: 165).

Cep telefonu kullanıcı sayısındaki dikkate değer bir artışın yanı sıra, cep telefonlarının ve İnternet Protokolü (IP) tabanlı ağların yakınsamasıyla beraber son birkaç yıl içerisinde cep telefonlarının artan ödeme gücüne tanıklık edilmiştir (Chandra, 2010: 562). Önümüzdeki yıllarda mobil uygulamaların kişisel ve profesyonel düzeyde hayatımızın ayrılmaz bir parçası olacağı tahmin edilmektedir. Karnouskos ve Fokus (2004)'a göre mobil uygulamalardan biri olan mobil ödemeler son zamanlarda hızla gelişmekte olan, umut verici ve heyecan verici bir alandır. Özellikle cep telefonları aracılığıyla hizmet eden mobil reklamcllı, mobil oyun, mobil uzaktan eğitim ve mobil ofisler gibi sınırsız mobil ticaret uygulamaları arasında, mobil ödeme sistemleri her an ve her yerde ödeme imkânı sunmasıyla birlikte en önemli mobil uygulamalardan biridir. Mobil cihazlar sıklıkla dijital içerikler (logo, haber, müzik veya oyunlar vb.), biletler, park ücretleri, faturalar veya elektronik ödeme hizmetlerine erişmek gibi çeşitli ödeme senaryolarında kullanılabilir (Dahlberg vd., 2008: 166). Ayrıca mobil cihazlar ile fiziksel mallar için de ödeme yapmak mümkündür. Bir ödemeyi başlatmak, etkinleştirmek ve onaylamak için mobil iletişim cihazını kullanan herhangi bir ödeme işlemi mobil ödeme sistemi olarak adlandırılabilir (Chandra, 2010: 563). Altyapı, hükümet düzenlemeleri ve bunları kullanabilen yeni mobil cihazlardaki ilerlemeler nedeniyle mobil ödemeye gösterilen ilgi son yıllarda önemli ölçüde artmıştır. Ayrıca, nakit esash ödemelerin mobil ödemelerle değiştirilmesiyle toplumsal, ekonomik ve verimlilik kazanımları önerilmekte ve bu durum yenilikçi iş modellerini yönlendirebilmektedir (MolinaCastillo vd., 2020: 2).

Mobil ödemeler, mobil kredi kartı veya mobil cüzdan gibi bir mobil ödeme araciyla gerçekleştirilir. Bu mobil ödeme araçlarına ek olarak, çoğu elektronik ve birçok fiziksel ödeme aracı gündeme gelmiştir. Mobil ödemeler, diğer tüm ödemeler gibi genel olarak iki kategoriye ayrılmaktadır. İlki, günlük satın alma ödemeleri bir diğeri ise fatura ödemeleridir. Satın alma işlemlerinde mobil ödemeler; nakit, çek, kredi kartı ve banka kartlarıyla yapılmaktadır. Faturalar için yapılan mobil ödemeler ise genellikle para transferleri, internet bankacılığı ödemeleri ve otomatik ödeme talimatları gibi 
hesap tabanlı ödeme araçlarına erișim sağlamaktadır (Dahlberg vd., 2008: 166). 2000'li yılların başında, mobil ödeme sistemleri önemli bir konu haline gelmiștir. Bu bağlamda elektronik ödemelere erişim ve internet bankacılığı dâhil olmak üzere yüzlerce mobil ödeme hizmeti tüm dünyada tanitılmıştır. Ancak bu sistemlerin çoğu çarpıcı bir şekilde başarısız olmuştur (Dahlberg vd., 2008: 166). Fiili standartları olmaksızın bir arada bulunan çok çeşitli mobil ödeme teknolojileri pazarda yüksek karmaşıklık yaratmaktadır. Mobil ödemelerden bazılarının ödemeleri doğrulaması ve yetkilendirmesi gerekirken (örneğin, PIN kodlarını girerek, jetonları otomatik olarak indirerek veya parmak izi vb.), bazıları ise hizmeti ve ne tür bir işlevsellik bekleyeceğini (örneğin, sadece ödeme, sadakat kartları ve elektronik makbuzlar gibi katma değerli özellikler) netleştirmemektedir (Molina-Castillo vd., 2020: 2). Bununla birlikte internet tabanlı bilgilerin artışı ile tüketiciler mal ve hizmet alışverişi için geleneksel olmayan yöntemlere daha aşina hale gelmiştir. Amazon, eBay ve Expedia gibi sanal vitrinlerin inanılmaz büyümesi ve Kuzey Amerika'daki tüm bilgisayar kullanıcılarının yaklaşık \%70'inin düzenli olarak internet üzerinden satın alma gerçekleştirmesi, tüketicilerin elektronik medya üzerinden alışveriş ve işlem yapmakla oldukça ilgilendiğini kanıtlamaktadır. Bu iki olayın ilerlemesi; bir mobil cihaz aracılığıyla işlem başlatma ve tamamlama arzusu da birleşik bir fikre yol açmıştır (Adrian, 2002: 5). Mobil ödeme kavramı ne kadar basit olursa olsun, m-ödeme altyapısının uygulanması, tüketicilerin $\mathrm{m}$ ödeme hizmetlerini benimsemesinin yanı sıra birçok konuyu çevrelemektedir örneğin, mobil işlem kimlik doğrulaması ve yetkilendirmesi için gerekli teknolojiler ve ödeme mutabakatı modellerinin hepsi çok olgunlaşmamıştır. Buna ek olarak, tüketiciler m-ödemeleri kabul etmeye istekli olduklarını ifade ediyor olsalar da bu tür yeni bir işlem yöntemi, bir gecede değişmeyecek köklü davranışları içinde barındırmaktadır. Bu karmaşıklık nedeniyle, m-ödeme sürecine dâhil olan tüm taraflar (finansal hizmet sağlayıcılarından kablosuz operatörlere kadar) mobil ödeme pazarını yönlendirecek dinamikleri tam olarak anlamalıdır (Adrian, 2002: 5).

E-ticaret, e-ödemeler ve mobil ödemeler kavramları birbiriyle güçlü bir etkileşim halindedir. $\mathrm{Bu}$ bağlamda e-ticaret dijital ve dijital olmayan mal ve hizmetlerin elektronik ortamda satışını kapsamaktadır. E-ödemeler fonların elektronik olarak ödenmesini sağlamak için gerekli sistem ve stratejileri ifade ederken, m-ödemeler her türlü mal veya hizmet için ödeme yapmak üzere doğrudan kablosuz bir cihazın kullanılmasını ifade etmektedir. Eticaret ve e-ödeme endüstrilerinin kesişimi olarak düşünülebilen mobil ödemeler, her iki endüstrinin tamamen işleme dayalı olan bir bileşenidir (Adrian, 2002: 6).

\subsection{Mobil ödeme hizmetleri davranışına etki eden faktörler}

\subsubsection{Performans beklentisi}

Performans beklentisi, bireyin sistemi kullanmasının iş performansında kazanç elde etmesine yardımcı olacağına inandığı derece olarak tanımlanmaktadır (Venkatesh vd., 2003: 447). Performans beklentisi; algılanan fayda, dış motivasyon, işe uyum, göreceli avantajlar ve sonuç beklentileri gibi çeşitli yapılardan benimsenmiştir. Kullanıcıların teknolojiyi kullanırken rahat hissetmeleri, teknolojinin performans beklentilerini artıracaktır (Rosnidah vd., 2019: 124). Bu bağlamda araştırmada aşağıdaki hipotez önerilmektedir:

$\mathrm{H}_{1}$ : Mobil ödeme hizmetlerine yönelik performans beklentisi, müşterinin mobil ödeme hizmetleri kullanım davranışı üzerinde pozitif bir etkiye sahiptir.

\subsection{2. Çaba beklentisi}

Çaba beklentisi kavramı, sistemin kullanımı ile ilgili kolaylığın derecesi olarak ifade edilmektedir (Venkatesh et al, 2003: 450). Kullanıcıların bir teknolojiyi kullanma kolaylığına ilişkin anlayış düzeyidir. Kullanıcılar teknoloji kullanımının kolay 
olduğunu düşündüklerinde, performans beklentisi artmaktadır. Bu bağlamda mobil ödeme kullanımı daha kolaydır ve geleneksel ödeme yöntemlerine kıyasla ödeme süreçlerini etkili bir şekilde kolaylaştırır dolayısıyla kullanıcılar mobil ödemeleri kullanma eğilimindedirler (Rosnidah vd., 2019: 124). Bu bilgiler doğrultusunda araștırmada aşağıdaki hipotez önerilmektedir:

$\mathrm{H}_{2}$ : Mobil ödeme hizmetlerine yönelik çaba beklentisi, müşterinin mobil ödeme hizmetleri kullanım davranışı üzerinde pozitif bir etkiye sahiptir.

\subsubsection{Sosyal etki}

Sosyal etki, bireylerin hayatında önemli bir yeri olan grupların, yeni sistemi kullanması gerektiğine inandığı algılama derecesi olarak ifade edilmektedir (Venkatesh et al, 2003: 451). Arkadaş, aile, sınıf arkadaşları ve sosyal gruplar gibi çeşitli grup görüşlerinden etkilenen bir teknoloji algısıdır. Sosyal etki, bireyin belirli eylemleri gerçekleştirirken çeşitli grupların görüşlerini algılaması olarak tanımlanmaktadır. Kullanıcılar, bir grup kullanıcıda yüksek sosyal statü algıladıklarında bu teknolojinin kullanımı hakkında iyi bir izlenime sahip olacaklardır (Rosnidah vd., 2019: 124). $\mathrm{Bu}$ doğrultuda araştırmada aşağıdaki hipotez önerilmektedir:

$\mathrm{H}_{3}$ : Mobil ödeme hizmetlerine yönelik sosyal etki, müşterinin mobil ödeme hizmetleri kullanım davranışı üzerinde pozitif bir etkiye sahiptir.

\subsubsection{Kolaylaştırıcı koşullar}

Bireylerin sistemin kullanımını desteklemek için bir organizasyonel ve teknik altyapının var olduğuna inandığı derecedir (Venkatesh et al, 2003: 453). Bu kolaylaştırıcı koşullar, ödeme sağlayıcıları tarafından satış noktaları gibi pratik durumlarda mobil ödeme yapmak için hizmetleri ve altyapıyı kullanma desteği olabilmektedir. Bu tür kolaylaştırıcı koşullar, piyasadaki çok sayıda standart, platform, teknoloji ve teklif göz önüne alındığında özellikle önemlidir. Bir kişi, mobil ödeme hizmetlerini kullanmak için gerekli altyapı ve desteğin mevcut olduğuna inandığında, mobil ödemeleri kullanma olasılığı daha yüksektir bu durum da mobil ödeme hizmetlerinin gerçek kullanımını etkilemektedir (Molina-Castillo vd., 2020: 4). Bu bilgiler ışığında araştırmada aşağıdaki hipotez önerilmektedir:

$\mathrm{H}_{4}$ : Mobil ödeme hizmetlerine yönelik kolaylaştırıcı koşullar, müşterinin mobil ödeme hizmetleri kullanım davranışı üzerinde pozitif bir etkiye sahiptir.

\subsubsection{Bilgi kalitesi}

Bilgi kalitesi, anlamsal başarıyı ölçen bir ölçüdür. Amaçlanan bilginin aktarılmasında sistemin başarısını ifade etmektedir. (Delone ve McLean, 2003: 10). Bu doğrultuda araştırmada aşağıdaki hipotez önerilmektedir:

H5: Mobil ödeme hizmetlerine yönelik bilgi kalitesi, müşterinin mobil ödeme hizmetleri kullanım davranışı üzerinde pozitif bir etkiye sahiptir.

\subsubsection{Sistem kalitesi}

Sistem kalitesi, teknik açıdan bir hizmetin başarısının ölçüsü olarak tanımlanır (Delone ve McLean, 2003: 10). Sistem kalitesi ile ölçülen teknik özelliklere örnek olarak kullanılabilirlik, uygunluk, güvenilirlik, uyarlanabilirlik ve yanıt verme süresi verilebilir (Delone ve McLean, 2003: 24). Bu bağlamda araştırmada aşağıdaki hipotez önerilmektedir:

$\mathrm{H}_{6}$ : Mobil ödeme hizmetlerine yönelik sistem kalitesi, müşterinin mobil ödeme hizmetleri kullanım davranışı üzerinde pozitif bir etkiye sahiptir.

\subsubsection{Hizmet kalitesi}

Hizmet sağlayıcısı tarafından sağlanan genel desteği ifade etmektedir. Hizmet kalitesi, sistemin güvence, empati ve yanıt verme yeteneğini ortaya koymaktadır (Delone ve McLean, 2003: 25). Bu faktör, müşteriler tarafından kullanılan teknolojinin gizlilik, güvenlik, pratiklik, yararlılık, tasarım ve eğlencenin sağlayıcılar tarafından ortaya koyulduğunu göstermektedir (Stamati ve 
Williams, 2014: 129). Bu bilgiler ışığında araştırmada aşağıdaki hipotez önerilmektedir:

H7: Mobil ödeme hizmetlerine yönelik hizmet kalitesi, müşterinin mobil ödeme hizmetleri kullanım davranışı üzerinde pozitif bir etkiye sahiptir.

\subsubsection{Kullanıcı tatmini}

Mobil ödeme uygulamaları, tüketicilerin kişisel ihtiyaçlarına göre hemen hemen her yerden ödeme aktiviteleri yapmalarını sağlayan yaygın ve kişiselleştirilmiş finansal teknolojilerdir. Ayrıca, bu uygulamalar tüketicileri tatmin etmek için Walmart, Starbucks ve KFC'de çeşitli ödeme senaryolarını desteklemektedir (Yang vd., 2020: 3). Bu çalışmada, mobil ödeme hizmetleri kullanımının kullanıcı tatmini üzerindeki etkisi incelenmiştir. Kullanıcı tatmini, șirketlerin gerçekleștirdikleri uygulamalarına iç veya dış müşterileri için değer yaratmasına yardımcı olma derecesidir (Delone ve McLean, 2003: 20). Kullanıcı tatmini boyutu, müşterilerin e-ticaret sistemi hakkındaki görüşlerini ölçmektedir ve bilgi edinmekten, satın alma, ödeme, makbuz ve edinilen hizmetlere kadar tüm müșteri deneyimi döngüsünü kapsamalıdır (Delone ve McLean, 2003: 25). Bu doğrultuda araştırmada aşağıdaki hipotez önerilmektedir:

H8: Mobil ödeme hizmetlerine yönelik kullanım davranışı, müșterinin mobil ödeme hizmetleri kullanıcı tatmini üzerinde pozitif bir etkiye sahiptir.

\subsection{Mobil ödeme hizmetleri ile ilgili literatür taraması}

Günümüzde m-ödeme bilgi teknolojisi alanında önemli bir araştırma alanı haline gelmektedir. Her ne kadar çok sayıda sektör m-ödemeyi farklı bağlamlarda benimsemiş olsa da benimsenmesini etkileyen faktörler hala belirgin değildir. Belirli bir yeni teknolojinin benimsenmesini incelemek için farklı teoriler /modeller geliştirilmiştir. Ampirik çalışmalarda en sık kullanılan ve onaylanan modellerden biri UTAUT modelidir. Al-Saedi vd., (2019) çalışmasında UTAUT'u teorik model olarak ele alan ve m-ödeme benimsemelerini içeren 25 araștırma makalesini sistematik olarak gözden geçirmiş ve analiz edilen çalışmaların \%48'inin sanayi sektörlerinde gerçekleştirildiğini ortaya koymuştur. Buna ek olarak, analiz edilen çalışmaların \%80'i temel olarak veri toplama aracı olarak anket formlarını kullanmışlardır.

Tablo 1: Mobil ödeme hizmetlerinin benimsenmesi ile ilgili çalıșmalar

\begin{tabular}{|c|c|c|c|}
\hline $\begin{array}{l}\text { Referans - } \\
\text { Veri kaynağı }\end{array}$ & $\begin{array}{l}\text { Baz } \\
\text { Model }\end{array}$ & Boyutlar & Diș Değisşkenler \\
\hline $\begin{array}{l}\text { Schierz vd., } 2010 \\
\text { Almanya-1447 } \\
\text { katılımcı }\end{array}$ & TAM & $\begin{array}{l}\text { Algılanan uyumluluk, bireysel } \\
\text { hareketlilik, bireysel normlar, } \\
\text { algılanan fayda, algılanan } \\
\text { güvenlik, algılanan kullanım } \\
\text { kolaylığı }\end{array}$ & $\begin{array}{l}\text { Kullanım tutumu, } \\
\text { kullanım niyeti }\end{array}$ \\
\hline $\begin{array}{l}\text { Hongxia vd., } \\
2011 \text { Çin-186 } \\
\text { üniversite } \\
\text { öğrencisi }\end{array}$ & UTAUT & $\begin{array}{l}\text { Algılanan risk, maliyet, } \\
\text { performans beklentisi, çaba } \\
\text { beklentisi, sosyal etki, } \\
\text { kolaylaștırıcı koşullar }\end{array}$ & Davranışsal niyet, \\
\hline $\begin{array}{l}\text { Zhou, } 2013 \\
\text { Çin-195 katılımcı }\end{array}$ & $\begin{array}{l}\text { D\&M IS } \\
\text { Success } \\
\text { Model }\end{array}$ & $\begin{array}{l}\text { Sistem kalitesi, bilgi kalitesi, } \\
\text { servis kalitesi, }\end{array}$ & $\begin{array}{l}\text { Güven, akıss, } \\
\text { tatmin, kullanım } \\
\text { niyetinde } \\
\text { devamlllı }\end{array}$ \\
\hline $\begin{array}{l}\text { Koenig-Lewis vd., } \\
2015 \text { Fransa-316 } \\
\text { katılımcı }\end{array}$ & $\begin{array}{l}\text { TAM- } \\
\text { UTAUT }\end{array}$ & $\begin{array}{l}\text { Algılanan zevk, sosyal etki, } \\
\text { algılanan risk, algılanan } \\
\text { kullanım kolaylığı, algılanan } \\
\text { fayda }\end{array}$ & $\begin{array}{l}\text { Kullanım niyeti, } \\
\text { kullanım }\end{array}$ \\
\hline $\begin{array}{l}\text { Slade vd., } 2015 \\
\text { İngiltere-268 } \\
\text { katılımcı }\end{array}$ & UTAUT & $\begin{array}{l}\text { Çaba beklentisi, performans } \\
\text { beklentisi, sosyal etki, } \\
\text { yenilikçilik, algilanan risk, } \\
\text { güven }\end{array}$ & Davranışsal niyet \\
\hline $\begin{array}{l}\text { Abrahão vd., } \\
2016 \\
\text { Brezilya- } 605 \\
\text { katılımcı }\end{array}$ & UTAUT & $\begin{array}{l}\text { Performans beklentisi, çaba } \\
\text { beklentisi, sosyal etki, algllanan } \\
\text { risk, algılanan maliyet, gerçek } \\
\text { kullanım }\end{array}$ & Davranışsal niyet \\
\hline $\begin{array}{l}\text { Aslam vd., } 2017 \\
\text { Karachi, } \\
\text { Pakistan- } 335 \\
\text { katılımcı }\end{array}$ & TAM & $\begin{array}{l}\text { Algılanan güvenlik, algılanan } \\
\text { uyumluluk, algılanan fayda, } \\
\text { algılanan kullanım kolaylı̆̆ı, } \\
\text { bireysel normlar }\end{array}$ & $\begin{array}{l}\text { Kullanım tutumu, } \\
\text { kullanım niyeti }\end{array}$ \\
\hline $\begin{array}{l}\text { Khalilzadeh vd., } \\
2017 \text { Kuzey } \\
\text { Amerika- } 412 \\
\text { restoran } \\
\text { müşterisi }\end{array}$ & $\begin{array}{l}\text { TAM- } \\
\text { UTAUT }\end{array}$ & $\begin{array}{l}\text { Kolaylaştırıcı koşullar, sosyal } \\
\text { etki, algılanan güvenlik, güven, } \\
\text { faydacı performans beklentisi, } \\
\text { hedonik performans beklentisi, } \\
\text { çaba beklentisi, özyeterlik, } \\
\text { performans riski, gizlilik riski }\end{array}$ & $\begin{array}{l}\text { Tutum, } \\
\text { davranıșsal niyet }\end{array}$ \\
\hline $\begin{array}{l}\text { Mun vd., } 2017 \\
\text { Malezya-300 } \\
\text { katılımcl }\end{array}$ & TAM & $\begin{array}{l}\text { Algılanan fayda, algılanan } \\
\text { kullanım kolaylığı, algılanan } \\
\text { inanınırlık, sosyal etki }\end{array}$ & Kullanma niyeti \\
\hline $\begin{array}{l}\text { Luna vd., } 2018 \\
\text { İspanya-742 } \\
\text { katıllımcl }\end{array}$ & TAM & $\begin{array}{l}\text { Algılanan kullanım kolaylığı, } \\
\text { algılanan fayda, algıllanan } \\
\text { güvenlik, bireysel normlar }\end{array}$ & $\begin{array}{l}\text { Tutum, kullanım } \\
\text { niyeti }\end{array}$ \\
\hline $\begin{array}{l}\text { Shankar ve Datta, } \\
2018 \\
\text { Hindistan-381 } \\
\text { katılımcı }\end{array}$ & TAM & $\begin{array}{l}\text { Algılanan kullanım kolaylı̆̆ı̆, } \\
\text { algılanan fayda, güven, öz } \\
\text { yeterlilik, yenilikçilik bireysel } \\
\text { normlar }\end{array}$ & $\begin{array}{l}\text { Mobil ödemeyi } \\
\text { benimseme }\end{array}$ \\
\hline $\begin{array}{l}\text { Rosnidah } \\
\text { vd.,2019 } \\
\text { Endonezya- } 125 \\
\text { katılımcl }\end{array}$ & UTAUT & $\begin{array}{l}\text { Performans beklentisi, çaba } \\
\text { beklentisi, sosyal etki, } \\
\text { kolaylaştırıcı koşullar }\end{array}$ & $\begin{array}{l}\text { Davranışsal niyet, } \\
\text { kullanım } \\
\text { davranıșı }\end{array}$ \\
\hline $\begin{array}{l}\text { Türker, } 2019 \\
\text { Türkiye-485 } \\
\text { katılımcı }\end{array}$ & TAM & $\begin{array}{l}\text { Mobil ödeme sistemlerine } \\
\text { yönelik öncül algılar, algılanan } \\
\text { kullanım kolaylı̆̆ algılanan } \\
\text { fayda, güven }\end{array}$ & $\begin{array}{l}\text { Mobil ödeme } \\
\text { sistemleri } \\
\text { kullanma niyeti }\end{array}$ \\
\hline
\end{tabular}

Yapılan kapsamlı literatür araştırması, mödeme benimsemesini incelemek için kullanılan UTAUT modelinde, algllanan risk ve algılanan güven boyutlarının en sık kullanılan 


\section{E. DURUKAL - K. ARMAN}

faktörler olduğunu vurgulamaktadır. $\mathrm{Bu}$ çalışmada yapılan literatür taraması, m-ödeme konusunda daha fazla araştırma yapmak isteyen araştırmacılar için kapsamlı bir referans sunmaktadır. Mobil ödeme hizmetleri ile ilgili çalışmalar Tablo 1'de özetlenmektedir.

Schierz vd., (2010) çalışmasında, tüketicilerin mobil ödeme hizmetlerini kabul etmesini belirleyen faktörleri araştırmıştır. Modelde algilanan uyumluluk, bireysel hareketlilik, sübjektif norm, algılanan fayda, algılanan güvenlik ve algılanan kullanım kolaylığı faktörleri ele alınmıştır. Almanya'da online anket yoluyla 1447 katılımcıdan kullanılabilir veri elde edilmiștir. Çalıșmada elde edilen bulgulara göre, algılanan uyumluluk, bireysel hareketlilik ve öznel normlar, bireylerin mobil ödeme hizmetlerini kullanma tutumunu önemli ölçüde etkilemektedir. Katılımcıların mobil hizmetlere yönelik kullanım tutumu ve kullanım niyeti arasında pozitif yönde anlamlı bir ilișki vardır. Çalışma, mobil ödeme hizmetlerinin tüketici tarafından kabul edilmesine ilişkin kapsamlı bir dizi önemli faktörü vurgulamaktadır. Hongxia vd., (2011) çalışmasında, Çin'deki mobil ödeme kabulünün belirleyicilerini araştırmış olup, kullanıcının mobil ödemeyi kabul etmesinde, performans beklentisi ve sosyal etkinin itici güçler olduğu, maliyet ve algılanan risklerin ise engeller olduğu ampirik olarak test edilmiștir. Performans beklentisi ve sosyal etki, hizmetlerin benimsenmesinin olumlu öncüllerini oluştururken, çaba beklentisi ve kolaylaştırıcı koşullar değildir. Algılanan riskin ve maliyetin hizmetlerin benimsenmesi üzerinde olumsuz etkisi vardır, ancak algılanan risk davranışsal niyetin aracılık etkisi olmaksızın gerçek kullanımı etkilemektedir. Zhou (2013) çalışmasında, bilgi sistemleri başarı modeline (D\&M IS Success Model) dayanarak, mobil ödeme hizmetlerini devamlı kullanma niyetini etkileyen faktörleri belirlemiștir. Veriler, Çin'deki iki ana telekomünikasyon operatörünü temsil eden servis mağazalarından toplanmıştır. 195 mobil ödeme hizmetleri kullanıcısından toplanan veriler yapısal eşitlik modeli ile analiz edilmiștir. Çalıșmada ele alınan boyutlar: sistem kalitesi, bilgi kalitesi, servis kalitesi, güven, akış ve tatmin ve mobil ödeme hizmetlerini kullanma niyetinde devamlılıktır. Çalışmadan elde edilen sonuçlara göre hizmet kalitesi güveni etkileyen ana faktör olarak bulunmuştur. Sistem kalitesinin ise tatmini etkileyen temel faktör olduğu ortaya çıkmıştır. Bilgi kalitesi ve hizmet kalitesi akışı etkilemektedir. Mobil ödeme hizmetlerine karşı duyulan güven, akış ve kullanıcı tatmini mobil ödeme hizmetlerini kullanma devamlılığını etkilemektedir. Koenig-Lewis vd., (2015) çalıșmasında, mobil ödeme kabulünü anlamak için algılanan zevk, sosyal etki, bilgi ve algılanan riski birleştirerek bu çerçeveleri genişletmektedir. Yerleşik teorilerin kopyaları, gençlerin mobil ödemeyi benimsemelerinin yeni bir bağlamında test edilmektedir. Sonraki hipotezler, çevrimiçi bir anket $(\mathrm{N}=316)$ kullanarak genişletilmiş bir teorik çerçeveyi test etmektedir. Genişletilmiş model, kullanım amacındaki varyasyonun \%62'sini açıklayarak önceki modelleri geliştirmektedir. Beklentilere karşı, algılanan kullanım kolaylığının algılanan fayda ve kullanım niyeti üzerinde anlamlı bir etkisi olmamıștır. Çalışma, kabul edinme niyeti üzerinde doğrudan etkisi olmayan ancak algılanan kullanım kolaylığı ve kullanışlılığı üzerinde önemli bir etkisi olmayan algllanan zevk anlayışının ilerlemesine katkıda bulunmaktadır. Sosyal etki ve algılanan eğlencenin algılanan riski azalttığını belirterek katkı yapılmıştır. Kullanım niyetinin ise gerçek kullanım üzerinde olumlu bir etkisi olmaktadır. Slade vd., (2015) çalışmasında, İngiltere'de mobil ödeme hizmetlerini kullanmayan bireylerin mobil ödeme hizmetlerini benimseme niyetlerini etkileyen faktörleri araştırmıştır. İngiltere'de anket yoluyla 268 katılımcıdan kullanılabilir veri elde edilmiştir. Elde edilen bulgulara göre, mobil ödeme hizmetlerini kullanmayan bireylerin mobil ödemeyi kabul etme niyetlerini performans beklentisi, sosyal etki, yenilikçilik ve algılanan risk önemli ölçüde etkilemektedir, ancak çaba beklentisi mobil ödemeyi kabul etme niyeti üzerinde herhangi bir etkiye sahip değildir. 
Ayrıca mobil ödeme hizmetlerini bilen bireyler ile bilmeyen bireylerin davranışsal niyetleri üzerindeki güven boyutunun etkisi arasında anlamlı bir farklılık ortaya çıkmıştır. Abrahão vd., (2016) çalışmasında, UTAUT modeline dayanarak mevcut Brezilyalı cep telefonu tüketicileri açısından mobil ödeme hizmetlerini değerlendirilmeyi amaçlamaktadır. Anket, Güneydoğu Brezilya'da faaliyet gösteren bir telekomünikasyon şirketinin mobil müşterileriyle (605 katılımcı) ile gerçekleştirilmiştir. Yapısal eşitlik modellemesi kullanılarak davranışsal niyetin \%76'sı performans beklentisi, çaba beklentisi, sosyal etki ve algılanan risk yoluyla açıklanmıştır. Algılanan maliyet \%5 düzeyde istatistiksel olarak anlamlı bulunmamıştır. Sonuçlar, ödeme pazarındaki katılımcılara yönelik olarak, performans, kullanım rahatlığı, güvenli mobil ödeme kapsamında hizmet geliştirmek için bir rehber görevi görmektedir. Aslam vd., (2017) çalışmasında, mobil ödeme hizmetlerinin uygulanmasına yönelik tüketicilerin davranışlarını, bu davranışa karşı tutumlarını etkileyebilecek faktörleri ve bu tutumların nasıl değiștiğini araştırmaktadır. Çalışmada, algılanan güvenlik, algllanan uyumluluk, algılanan fayda, algılanan kullanım kolaylı̆̆ı ve öznel normlar boyutları kullanılmıştır. Pakistan'da 335 katılımcıdan online anket yoluyla veri toplanılmıștır. Çalışmada elde edilen sonuçlar algılanan uyumluluk, algılanan kullanışlılık ve bireysel normlar, mobil ödeme hizmetlerinin kullanımına yönelik tutumun önemli bir göstergesi iken, algllanan güvenlik ve algılanan kolaylık boyutlarının, mobil ödeme hizmetlerini kullanmaya yönelik tutum üzerindeki etkisi önemsizdir. Khalilzadeh vd., (2017) çalışmasında, restoran endüstrisinde NFC tabanlı MP teknolojisi kabulünün belirleyicilerini inceleyen entegre bir model sağlamayı amaçlamaktadır. Birleştirilmiş Teknoloji Kabul ve Kullanım Teorisi (UTAUT) ve Teknoloji Kabul Modeli'ni (TAM) birleștiren model, 412 restoran müșterisinden toplanan veriler kullanılarak yapısal eşitlik modellemesi ile test edilmiştir. Çalışma sonuçları, önerilen modelin orijinal UTAUT modelinden yaklaşık
\%20 daha fazla açıklayıcı güç ve öngörücü doğruluk sağladığını ve müşterilerin restoranda NFC tabanlı MP teknolojisini kullanma niyetleri üzerinde; risk, güvenlik ve güvenin etkilerine dair güçlü kanıtlar göstermiştir. Toplam etki, tutum, güvenlik ve risk boyutları, müșterilerin davranıșsal niyetleri üzerinde en önemli etkiye sahiptir. Çalıșma sonuçları ayrıca risk, güvenlik ve güvenin diğer kritik yapıların (çaba beklentisi, hedonik ve faydacı performans beklentisi, tutumu ve niyeti) doğrudan ve dolayl etkileri olan önemli belirleyiciler olduğunu da göstermektedir. Mun vd., (2017) çalışmasında, tüketicilerin mobil ödeme hizmetlerini kullanma niyeti ile algılanan kullanışlılık, algılanan kullanım kolaylığı, algılanan güvenilirlik ve sosyal etki arasındaki ilişkiyi ele almıştır. Malezya'da 300 katılımcıdan anket yoluyla veri toplanılmıştır. Bulgular modelde ele alınan dört boyutunda, tüketicilerin mobil ödeme servislerini kullanma niyetini etkilemede önemli bir etkiye sahip olduğunu ortaya koymaktadır. Boyutlar içerisindeki algılanan yararlılık, kullanma niyeti üzerinde en önemli faktör olarak ortaya çıkmıştır. Luna vd., (2018) çalışmasında, tüketicilerin SMS, NFC ve QR (Hızlı Yanıt) mobil ödeme sistemlerini kabul etmesini belirleyen faktörleri karşılaștırmanın yanı sıra, bu mobil ödeme sistemlerinin ödeme aracl olarak benimsenmesini etkileyen temel faktörleri belirlemektedir. Çalışma için İspanya'da 287 adet SMS, 287 adet NFC ve 168 QR ödeme sistemleri için anket uygulanarak toplam 742 anket yapılmıștır. Üç ödeme sisteminde de tutumu etkileyen en önemli boyutlardan biri bireysel normlardır. Algılanan fayda, algılanan kullanım kolaylığı, algılanan güvenlik boyutları, mobil ödeme sistemlerini kullanma niyetinin belirleyicisi olarak ortaya çıkmaktadır. Tutum da kullanım niyetini önemli ölçüde etkileyen bir faktördür. Shankar ve Datta (2018) çalışmasında, Hindistan'da mobil ödeme benimseme niyetini etkileyen faktörleri, TAM ile, dört kullanıcı merkezli boyutu (güven, öz yeterlilik, yenilikçilik, bireysel normlar) dahil ederek belirlemeyi amaçlamaktadır. Çalışma 
381 katılımcı ile Hindistan'da gerçekleşmiştir. Çalışmada elde edilen sonuçlara göre algılanan kullanım kolaylığı, algılanan fayda, güven ve öz yeterlilik boyutları mobil ödeme benimseme niyetinde önemli olumlu bir etkiye sahiptir. Ancak bireysel normlar ve yenilikçilik boyutları mobil ödemeyi benimseme niyetinde önemli bir etkiye sahip değildir. Algılanan kullanım kolaylığı ve algılanan fayda boyutları Hindistan'da mobil ödeme hizmetlerinin benimsemesinde en etkili boyutlar olarak ortaya çıkmaktadır. Rosnidah vd., (2019) çalışmasında, mobil ödeme kullanımının kabulünü etkileyen faktörleri incelemiş, çalışmanın sonuçları; performans beklentisi, çaba beklentisi ve sosyal etkinin davranışsal niyet üzerinde anlamlı bir olumlu etkisi olduğunu göstermektedir. Dahası, kullanım davranışı üzerindeki kolaylaştıııcı koşullar ve davranışsal niyet, mobil ödemeleri ödeme aracı olarak kullanma eğilimine yöneltmektedir. Çaba beklentisi diğer değişkenler arasında en büyük etkiye sahiptir. Böylece, mobil ödeme kullanımındaki konfor arttıkça, sürekli ödeme yapma niyeti de artar. Bu çalışma aynı zamanda bir kişinin mobil ödeme kullanma niyeti ne kadar yüksek olursa, mobil ödemeleri günlük hayatta kullanma olasılığının o kadar yüksek olduğunu kanıtlamaktadır. Bu çalışmada öne çıkan noktalardan biri, sosyal etkinin davranışsal niyet üzerinde az bir etkisi olduğudur. Kullanıcılar sosyal etkiye kıyasla günlük ihtiyaçlarını destekleyebilecek bir altyapıya ihtiyaç duymaktadır. Performans beklentisi ise, kullanıcıların mobil ödemeleri kullanmaya devam etme isteği üzerinde yüksek bir etkiye sahiptir. Türker, (2019) tez çalışmasında, tüketicilerin mobil ödeme sistemlerine yönelik olarak kullanım niyetlerini ve kullanım niyetlerini etkileyen faktörleri incelemiștir. Çalışma Türkiye'de online anket yoluyla yapılmış olup, 485 kullanılabilir veri elde edilmiştir. Çalışmada ele alınan boyutlar: mobil ödeme sistemlerine yönelik öncül algılar (sosyal etki, algılanan uyumluluk, algılanan güvenlik), algılanan kullanım kolaylığı, algılanan fayda ve güvendir. Çalışmadan elde edilen sonuçlara göre, algılanan kullanım kolaylığının algılanan fayda üzerinde doğrudan ve olumlu yönde bir etkisi olduğu saptanmıştır. Algllanan fayda ile mobil ödeme sistemlerini kullanma niyeti arasında ise olumlu bir ilişki vardır. Algılanan kullanım kolaylığı boyutu ise tüketicilerin mobil ödeme sistemlerini kullanma niyeti üzerinde doğrudan etkiye sahip değildir ancak algılanan fayda üzerinden kullanma niyetine dolaylı olarak etki etmektedir.

\section{ARAŞTIRMANIN METODU}

\subsection{Araştırma evreni ve örneklemi}

Araştırma evrenini, Türkiye'de mobil ödeme hizmetlerini kullanan müşteriler oluşturmaktadır. Evrenin tamamına erişmenin maliyet ve zaman gerekliliği göz önüne alındığında, çalışma ana kütleyi temsil edecek bir örneklem üzerinden yapılmıștır. Bu çalışmada kullanılan örneklem büyüklüğünün belirlenmesinde, Yazıcıoğlu ve Erdoğan tarafindan hazırlanan, belirli bir evreni temsil edebilen örneklem büyüklüğü tablosundan yararlanılmıștır (Yazıcıoğlu ve Erdoğan, 2004: 50). Söz konusu tablo, 0.05 örnekleme hatası ile yeterli örneklem büyüklüğünün 246 kişi olduğunu ortaya koymaktadır. Roscoe (1975), birçok çalışma için yeterli örneklem büyüklüğü sayısını 30'dan büyük ve 500'den küçük şeklinde ifade etmiștir. $\mathrm{Bu}$ araștırmada kullanılan örneklem grubunu, 2020-2021 öğretim yılı bahar yarıyılında Adnan Menderes Üniversitesi Nazilli İ̉BF'de öğrenim görmekte olan toplam 250 öğrenci oluşturmaktadır. Buna göre çalışmada ele alınan örneklem sayısının uygun/ yeterli olduğu düşünülmektedir.

\subsection{Anket soru formunun oluşturulması}

Anket soru formunda mobil ödeme hizmetlerine ilişkin 35 ifade yer almaktadır. Araștırmanın ölçeği, performans beklentisi (4 ifade), çaba beklentisi (4 ifade), sosyal etki (4 ifade), kolaylaştırıcı koşullar (4 ifade), bilgi kalitesi (4 ifade), sistem kalitesi (4 ifade), hizmet kalitesi (3 ifade), kullanım davranışı (4 ifade) ve kullanıcl tatmini (4 ifade) boyutlarından olușmaktadır (Delone ve McLean, 2003). Müşterilerin anket soru 
formunda verilen ifadelerini belirlemek için 5'li Likert ölçeği kullanılmıştır.

\subsection{Araştırmanın modeli}

$\mathrm{Bu}$ çalışma, DeLone ve McLean Bilgi Sistemleri Başarı Modelini (D\&M IS Success Model), Birleştirilmiş Teknoloji Kabul ve Kullanım Teorisi (UTAUT) ile birleştirmiştir. Pek çok teorik model, teknolojinin kullanıcı tarafindan kabul edilmesinden bahsetmektedir. Bu tür sekiz teori ve model, UTAUT'ı olușturmak üzere Venkatesh ve arkadaşları (2003) tarafından değerlendirilmiş ve sentezlenmiştir. Çoklu teknoloji benimseme modelleri analiz edildikten sonra, teknolojinin benimsenmesi için dört faktör; performans beklentisi, emek beklentisi, kolaylaştırıcı koşullar ve sosyal etki olarak bu teoride tanımlanmıștır (Soni vd., 2019: 362). UTAUT; yeni teknoloji tanıtımları için başarı olasılığını değerlendirmek, yeni sistemleri benimseme ve kullanma konusunda daha az eğilimli olabilecek kullanıcı popülasyonlarını hedefleyen müdahaleleri (eğitim, pazarlama vb.) kabul etmenin itici güçleri ortaya koymada yöneticiler için yararlı bir araç olmaktadır (Venkatesh et al, 2003: 426). DeLone ve McLean Bilgi Sistemleri Başarı Modeli'ne (IS) göre, sistem kalitesi ve bilgi kalitesi kullanımı ve kullanıcı tatminini etkilemekte ve bu iki faktör bireysel etkiye ve örgütsel etkiye neden olmaktadır (DeLone ve McLean 1992: 87). Delone ve McLean daha sonra güncellenmiș bir model geliștirerek hizmet kalitesini de modele bağımsız değişken olarak dahil etmişlerdir. Güncelleştirilmiş modele göre, sistem kalitesi, bilgi kalitesi ve hizmet kalitesi kullanım davranışı ve kullanıcı tatminini etkilemektedir. Bir önceki modelden farklı olarak güncelleștirilmiş model bu iki faktörün birtakım yeni faydalara neden olduğunu ortaya koymaktadır (Delone ve McLean, 2003: 24-25). D\&M IS Başarı Modeli'nde üç faktörden sistem kalitesi; teknik başarıyı, bilgi kalitesi; anlamsal başarıyı ve kullanıcı memnuniyeti ise etkinlik bașarısını ölçmektedir (Delone ve McLean, 2003: 10). Bu çalışmada ele alınan DeLone ve Mclean IS Success modeli; mobil ödeme hizmetlerinin bașarısını ölçmeyi sağlarken, UTAUT modeli mobil ödeme hizmetlerinin başarılı olmasına yol açan faktörleri ortaya koymaktadır. Bu çalışmada söz konusu iki model birleştirilerek ele alınan bağımsız değişkenler; hizmet kalitesi, bilgi kalitesi, sistem kalitesi, performans beklentisi, çaba beklentisi, sosyal etki, kolaylaştırıcı koşullar olup, bahsedilen değişkenlerin kullanım davranışı üzerindeki etkisi ortaya konulmuştur. Bu çalışma bağımsız değişken olarak kullanım davranışının da kullanıcı tatmini üzerindeki etkisini incelemektedir. Şekil 1'de araştırma modeli sunulmaktadır.

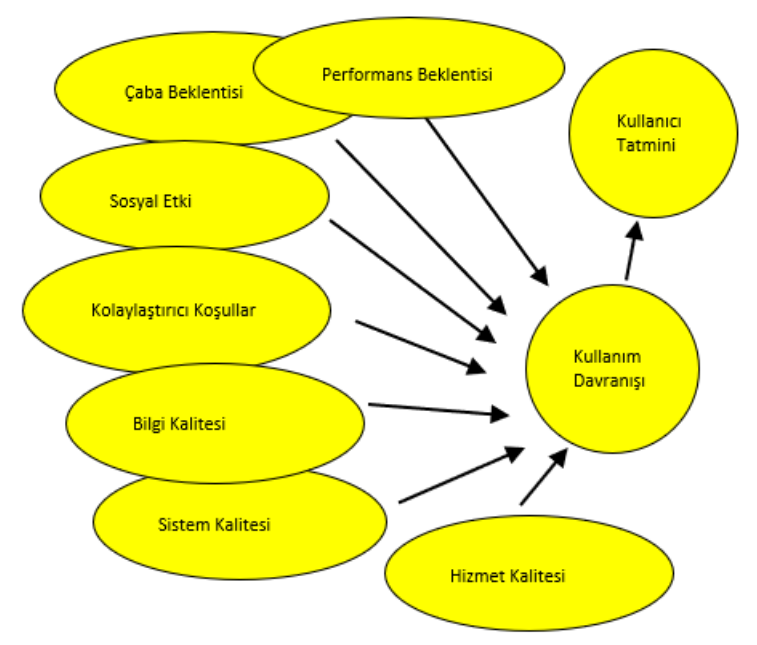

Şekil 1. Araştırmanın modeli

\section{BULGULAR}

Çalıșmada kullanılan yapısal eșitlik modeli, bazı olgulara dayanan bir yapısal teorinin analizine doğrulayıcl bir yaklaşım benimseyen istatistiksel bir yöntemdir (Byrne, 2009: 3). Çalışmada kullanılan Yapısal Eşitlik Modeli LISREL Programı yardımıyla analiz edilecektir.

Faktör analizi genellikle sosyal bilimlerde korelasyon matrislerine uygulanmaktadır. Bir faktör, değişkenler arasındaki ilişkileri (korelasyonları) açıklayabilen bir yapı veya boyut olarak tanımlanmaktadır (Kline, 1994: 13). Faktör analizi, birbiriyle ilişkili çok sayıda değişkenin daha az sayıda boyuta indirgenmesine izin veren analitik bir tekniktir. Faktör analizinin amacl, bir korelasyon matrisindeki maksimum ortak varyans miktarını açıklamak için en az sayıda açıklayıcı 


\section{E. DURUKAL - K. ARMAN}

kavram kullanmaktır (Rennie, 1997: 4). Önceden belirlenmiș faktörleri belirledikten sonra doğrulayıcı yöntemler, önceden belirlenmiş faktör modelinin "uyum iyiliğini" belirlemek için belirli bir veri setinde gözlemlenen teorik faktör yapılarını en uygun şekilde eşleştirmeye çalışmaktadır (Stapleton, 1997: 7). Doğrulayıcı faktör analizi (DFA) ise bir dizi gözlenen değişkenin faktör yapısını doğrulamak için kullanılan istatistiksel bir tekniktir. DFA, gözlemlenen değişkenler ve bunların altta yatan gizli yapıları arasında bir ilişkinin olup olmadığı hipotezini test etmeye yardımcı olmaktadır (Suhr, 2006: 1).

Araştırma kapsamında katılımcılara 315 anket formu dağıtılmış olup 25 anket formu katılımcıların hatalı ve eksik doldurması ve 40 anket formu da katılımcıların mobil ödeme hizmetlerini kullanmadığını belirtmesi nedeniyle analize dahil edilmemiş, dolayısıyla analizler 250 soru formu ile yürütülmüştür.

Çokluk ve arkadaşları (2010)'a göre faktör yük değeri; "maddelerin faktörlerle olan ilişkisini açıklayan bir katsayıdır". Genellikle işareti dikkate alınmaksızın 0.60 ve üstü faktör yük değeri yüksek; 0.30-0.59 arası faktör yük değeri orta düzeyde büyüklükler olarak tanımlanmakta olup, faktör yük değerleri değişken çıkartmada dikkate alınmaktadır (Büyüköztürk, 2002: 474). Comrey (1973) ise faktör yük değeri katsayısı için 0,45 üzeri değerleri madde seçimi için yeterli bir ölçüt olarak değerlendirmektedir. Tablo 2'de faktör yüklerine bakıldığında çalışmada yer alan tüm ölçeklerin (performans beklentisi, çaba beklentisi, sosyal etki, kolaylaştırıcı koşullar, bilgi kalitesi, sistem kalitesi, hizmet kalitesi, kullanım davranışı, kullanıcı tatmini) faktör yük değerlerinin 0,55 ile 0,89 arasında değișmekte olduğu görülmektedir. KD3 ifadesinin faktör yükü ise 0.45 'in altında $(0,17)$ olduğu için ölçekten çlkarılmıştır. Schumacker ve Lomax, (2010)'a göre $p<0.05$ anlamlılık düzeyinde, t-değeri 1.96'dan daha yüksek olduğunda model anlamlıdır. $\mathrm{Bu}$ değerin altında bir t-değeri olduğunda ise ilgili ifade ölçekten çıkarılmalıdır. Daha önceki sonuca benzer ssekilde KD3 ifadesinin $t$ değerinin de 1.96'nın altında olduğu (1.70) tespit edilmiştir.

Tablo 2: Kuramsal model için Yapısal Eşitlik Modeli analizi

\begin{tabular}{|c|c|c|c|c|c|c|}
\hline & & $\begin{array}{c}\text { Hata } \\
\text { Varyansları }\end{array}$ & $\begin{array}{c}\text { Yol } \\
\text { katsayıları }\end{array}$ & $\begin{array}{c}\mathrm{T}- \\
\text { değerleri }\end{array}$ & $\begin{array}{c}\text { Cronbach } \\
\text { Alfa }\end{array}$ & $\mathbf{R}^{2}$ \\
\hline \multirow{4}{*}{ 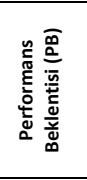 } & $\begin{array}{l}\text { Soru } 1 \\
\text { (PB1) }\end{array}$ & 0,23 & 0,81 & 7,55 & \multirow[t]{4}{*}{893} & 0,74 \\
\hline & $\begin{array}{l}\text { Soru } 2 \\
\text { (PB2) }\end{array}$ & 0,17 & 0,74 & 7,27 & & 0,76 \\
\hline & $\begin{array}{l}\begin{array}{c}\text { Soru } 3 \\
\text { (PB3) }\end{array} \\
\end{array}$ & 0,47 & 0,62 & 10,20 & & 0,45 \\
\hline & $\begin{array}{l}\text { Soru } 4 \\
(\mathrm{~PB} 4) \\
\end{array}$ & 0,38 & 0,63 & 9,91 & & 0,51 \\
\hline \multirow{4}{*}{ 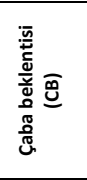 } & $\begin{array}{l}\text { Soru } 5 \\
\text { (CB1) }\end{array}$ & 0,27 & 0,67 & 9,30 & \multirow[t]{4}{*}{$\begin{array}{l}, 884 \\
\end{array}$} & 0,62 \\
\hline & $\begin{array}{l}\text { Soru } 6 \\
\text { (CB2) }\end{array}$ & 0,36 & 0,71 & 9,55 & & 0,59 \\
\hline & $\begin{array}{l}\text { Soru } 7 \\
\text { (CB3) }\end{array}$ & 0,20 & 0,73 & 8,17 & & 0,72 \\
\hline & $\begin{array}{l}\text { Soru } 8 \\
\text { (CB4) }\end{array}$ & 0,27 & 0,72 & 9,04 & & 0,65 \\
\hline \multirow{4}{*}{ 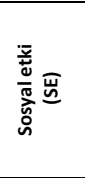 } & $\begin{array}{c}\begin{array}{c}\text { Soru } 9 \\
(\mathrm{SE} 1)\end{array} \\
\end{array}$ & 0,69 & 0,77 & 9,54 & \multirow[t]{4}{*}{843} & 0,46 \\
\hline & $\begin{array}{c}\text { Soru } 10 \\
\text { (SE2) }\end{array}$ & 0,54 & $\begin{array}{ll}0,87 \\
\end{array}$ & 8,51 & & 0,58 \\
\hline & $\begin{array}{c}\text { Soru } 11 \\
\text { (SE3) }\end{array}$ & 0,39 & 0,78 & 8,16 & & 0,61 \\
\hline & $\begin{array}{c}\text { Soru } 12 \\
\text { (SE4) }\end{array}$ & 0,35 & 0,81 & 7,59 & & 0,65 \\
\hline \multirow{4}{*}{ 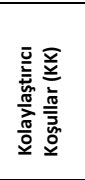 } & $\begin{array}{l}\text { Soru } 13 \\
\text { (KK1) }\end{array}$ & 0,26 & 0,68 & 8,70 & \multirow[t]{4}{*}{,778 } & 0,64 \\
\hline & $\begin{array}{c}\text { Soru } 14 \\
\text { (KK2) }\end{array}$ & 0,23 & 0,62 & 8,85 & & 0,63 \\
\hline & $\begin{array}{c}\text { Soru } 15 \\
\text { (KK3) }\end{array}$ & 0,19 & 0,65 & 8,10 & & 0,69 \\
\hline & $\begin{array}{c}\text { Soru } 16 \\
\text { (KK4) }\end{array}$ & 0,83 & 0,55 & 10,69 & & 0,26 \\
\hline \multirow{4}{*}{ 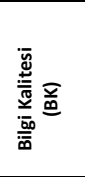 } & $\begin{array}{c}\text { Soru } 17 \\
\text { (BK1) }\end{array}$ & 0,29 & 0,69 & 9,49 & \multirow[t]{4}{*}{,870 } & 0,63 \\
\hline & $\begin{array}{c}\text { Soru } 18 \\
\text { (BK2) }\end{array}$ & 0,25 & 0,65 & 9,48 & & 0,63 \\
\hline & $\begin{array}{c}\text { Soru } 19 \\
\text { (BK3) }\end{array}$ & 0,23 & 0,71 & 8,98 & & 0,68 \\
\hline & $\begin{array}{c}\text { Soru } 20 \\
\text { (BK4) }\end{array}$ & 0,18 & 0,66 & 8,72 & & 0,71 \\
\hline \multirow{4}{*}{ 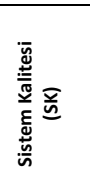 } & $\begin{array}{c}\text { Soru } 21 \\
\text { (KK1) }\end{array}$ & 0,36 & 0,63 & 10,04 & \multirow[t]{4}{*}{, 828} & 0,53 \\
\hline & $\begin{array}{c}\text { Soru } 22 \\
\text { (SK2) }\end{array}$ & 0,29 & 0,73 & 9,24 & & 0,65 \\
\hline & $\begin{array}{c}\text { Soru } 23 \\
\text { (SK3) }\end{array}$ & 0,27 & 0,74 & 9,01 & & 0,67 \\
\hline & $\begin{array}{c}\text { Soru24 } \\
\text { (SK4) }\end{array}$ & 0,53 & 0,66 & 10,35 & & 0,45 \\
\hline \multirow{3}{*}{ 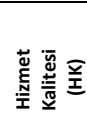 } & $\begin{array}{c}\text { Soru } 25 \\
\text { (HK1) }\end{array}$ & 0,23 & 0,77 & 8,41 & \multirow[t]{3}{*}{890} & 0,72 \\
\hline & $\begin{array}{c}\text { Soru } 26 \\
\text { (HK2) }\end{array}$ & 0,24 & 0,89 & 7,67 & & 0,76 \\
\hline & $\begin{array}{c}\text { Soru } 27 \\
\text { (HK3) }\end{array}$ & 0,24 & 0,83 & 8,05 & & 0,74 \\
\hline \multirow{3}{*}{ 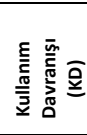 } & $\begin{array}{c}\text { Soru } 28 \\
\text { (KD1) }\end{array}$ & 0,50 & 0,67 & 10,63 & \multirow[t]{3}{*}{,778 } & 0,47 \\
\hline & $\begin{array}{c}\text { Soru } 29 \\
\text { (KD2) }\end{array}$ & 0,44 & 0,69 & 10,53 & & 0,52 \\
\hline & $\begin{array}{c}\text { Soru } 31 \\
\text { (KD4) }\end{array}$ & 0,58 & 0,62 & 10,77 & & 0,40 \\
\hline \multirow{4}{*}{ 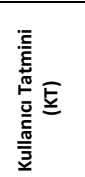 } & $\begin{array}{c}\text { Soru } 32 \\
\text { (KT1) }\end{array}$ & 0,25 & 0,70 & 9,35 & \multirow[t]{4}{*}{,895 } & 0,67 \\
\hline & $\begin{array}{c}\text { Soru } 33 \\
\text { (KT2) }\end{array}$ & 0,27 & 0,79 & 9,10 & & 0,69 \\
\hline & $\begin{array}{c}\text { Soru } 34 \\
\text { (KT3) }\end{array}$ & 0,16 & 0,75 & 8,07 & & 0,77 \\
\hline & $\begin{array}{c}\text { Soru } 35 \\
\text { (KT4) }\end{array}$ & 0,27 & 0,70 & 9,52 & & 0,65 \\
\hline \multicolumn{7}{|c|}{ Kaiser-Meyer-Olkin $(\mathrm{KMO})=0,947$} \\
\hline \multicolumn{7}{|c|}{ Açıklanan Varyans $(\%)=68,052$} \\
\hline
\end{tabular}

Verilerin analizi için ilk olarak içsel tutarlılık güvenilirliği analizi yapılmıştır. Likert tipi bir ölçekte içsel tutarlılık güvenilirliği, bir testin farklı yapılara ne kadar iyi hitap ettiğini ve güvenilir puanlar verdiğinin bir ölçüsüdür. Diğer yöntemlerin yanı sıra içsel tutarlılığı değerlendirmek için en yaygın yöntem Cronbach Alfa değeridir (Lee ve Kwag 2018: 
226). 0 ile 1 arasında değer alan Cronbach Alfa katsayısının 0.80 ile 1 aralı̆̆ında olması durumunda ölçek yüksek derecede güvenilir olarak yorumlanmaktadır (Kalaycl, 2006: 405). Yapılan güvenirlilik testi sonucunda Cronbach Alfa değerinin tüm ölçekler için 0,70'in üstünde bir değerde olduğu ortaya çıkmıș ve tüm ölçeklerin oldukça güvenilir olduğu tespit edilmiştir. Ankette yer alan tüm ifadelerin genel güvenilirliği ise 0,91 olarak tespit edilmiştir. Buna göre araştırma ölçeğinin oldukça güvenilir olduğu görülmektedir. Faktör analizinin uygulanabilmesi için KMO ve Bartlett Küresellik testi sonuçlarına bakılmalıdır. KMO testinin yapılma amacl, örneklem büyüklüğünün faktör analizi için yeterli olup olmadığını belirlemektir. KMO Değeri 1'e doğru yaklaştıkça veri setinin mükemmellik derecesi artmaktadır (Sharma, 1996: 116). Analiz sonucunda elde edilen KMO değeri 0,94 olarak bulunmuștur. Buna göre çalışmada ele alınan örneklem büyüklüğü faktör analizi için oldukça yeterlidir. Korelasyon matrisinin birim matrisi kararı için hipotez testi sonucu ortaya koyan Barlett Küresellik testi, $\mathrm{p}<0,05$ olması durumunda korelasyon matrisi birim matrisi olmamaktadır. Bu bağlamda ilgili veri seti için faktör analizi yapılabilmektedir (Özdemir, 2013: 316). Yapılan Bartlett Küresellik testi sonuçlarında elde edilen değerlere göre $(\chi 2$ : $6683,742, p=0,000$ ) ilgili veri seti için faktör analizinin yapılması uygundur.

Araştırmadaki ilgili yapının iyi ölçülmüş olduğunun göstergesi olarak, açıklanan varyansın yüksek olması gerekmektedir (Büyüköztürk, 2002: 479). Açıllanan varyansın kümülatif varyans üzerinden \%50'yi aşmış olması faktör analizinin önemli bir kriteri olarak değerlendirilmektedir (Yaşlıoğlu, 2017: 77).

Analiz sonucunda 34 maddeden oluşan dokuz faktörlü bir yapı elde edilmiștir. Söz konusu dokuz faktör, kümülatif varyansın \%68,05'ini açıklamaktadır. Hata varyansı, veri setine ilişkin varyansın açıklanamayan kısmı olarak tanımlanmaktadır (Yaşlıoğlu, 2017: 76). Bu bağlamda DFA'da hata varyansı değerinin düşük olması istenmektedir.

Ardından modifikasyon işlemine geçilmiştir. Buna göre çalışmada PB2 ve PB1, PB4 ve PB3, CB3 ve CB1, SE2 ve SE1, KK3 ve KK2, BK3 ve BK1, KD2 ve KD1 ifadeleri arasinda modifikasyon uygulanmıştır.

Tablo 3: Araştırma modelinin uyum indeksleri ve yapısal modeli

\begin{tabular}{|l|c|c|}
\hline Uyum Ölçüsü & Karar kriterleri & Araştırma Sonucu \\
\hline$\chi 2 /$ sd & $1<\chi 2<5$ & $1114.51 / 545=2,04$ \\
\hline $\begin{array}{l}\text { RMSEA (Root Mean Square Error of } \\
\text { Approximation }\end{array}$ & $0.05 \leq \mathrm{RMSEA} \leq 0,08$ & 0.065 \\
\hline GFI (Goodness of Fit Index) & GFI $\geq 0.95$ & 0,80 \\
\hline AGFI (Adjusted Goodness of Fit Index) & $\mathrm{AGFI} \geq 0,95$ & 0,76 \\
\hline NFI (Normed Fit Index) & $\mathrm{NFI} \geq 0,97$ & 0,97 \\
\hline NNFI (Non-Normed Fit Index) & $\mathrm{NNFI} \geq 0,97$ & 0,98 \\
\hline CFI (Comparative Fit Index) & $\mathrm{CFI} \geq 0,97$ & 0,98 \\
\hline RMR (Root Mean Square Residual) & $\mathrm{RMR} \leq 0.05$ & 0,05 \\
\hline SRMR (Standardized RMR) & $0.05<$ SRMR $\leq 0.10$ & 0,054 \\
\hline
\end{tabular}

Modifikasyon uygulaması sonrası Doğrulayıcı Faktör Analizi tekrarlanarak uyum ölçüleri hesaplanmıştır. Parametre tahmini, model testi ve belirli parametrelerin boyut ve öneminin değerlendirilmesi gibi modellemenin birçok yönü olmasına rağmen, tipik olarak uygunluk testi istatistiği ile model değerlendirmesi, modellemedeki en kritik adımı temsil etmektedir (Bentler ve Yuan, 1999: 181). Mutlak uyum indeksleri, modelin örnek verilere ne kadar uyduğunu belirlemektedir ve hangi önerilen modelin en üstün uyumu olduğunu göstermektedir. $\mathrm{Bu}$ önlemler, önerilen teorinin verilere ne kadar iyi uyduğuna dair en temel göstergeyi sağlamaktadır. Artımlı uyum indekslerinin aksine, hesaplamaları temel bir modelle karşılaştırmaya dayanmaz, bunun yerine modelin ne kadar iyi uyduğunun bir ölçüsüdür (Hooper vd., 2008: 53). Modelin verilere uygunluğu değerlendirilmelidir. Amaç, araștırmacının tahmini modelinde ölçülen ve gizli değişkenler arasındaki ilişkilerin belirlenmesini sağlamaktır (Weston ve Gore, 2006: 741). Araştırmanın uyum indeksleri sonuçları Tablo 3'te gösterilmektedir. 


\section{E. DURUKAL - K. ARMAN}

Ki-kare $(\chi 2)$ uyum indeksi, bir modelin uyumunu test etmede ilk incelenen uyum indeksidir. Ancak ki-kare testinde bir sınırlama vardır. Özellikle gözlemler 200'den büyük olduğunda ki-kare değeri örneklem büyüklügüne karşı oldukça duyarlıdır (Hoe, 2008: 78). Joreskog ve Sorbom'a (1993) göre, model uyumunu değerlendirmek için $\chi 2$ değerinin alternatif bir değerlendirilmesi olarak $\chi 2$ değerinin serbestlik derecesine bölünmesiyle elde edilen değer ( $\chi 2 / d f)$ incelenebilir. Bu nedenle bu çalışmada ( $\chi 2 / \mathrm{df})$ değeri ele alınmıştır. Söz konusu değer için 1 'den küçük değerler zayıf bir model uyumuna işaret etmekte olup, 5.0'den büyük değerler ise modelin geliștirilme ihtiyacını yansıtmaktadır (Schumacker ve Lomax, 2004: 82). Analiz sonucunda elde edilen değer $(2,04)$ modelin kabul edilebilir seviyede olduğunu göstermektedir. Browne ve Cudeck (1993)'e göre, RMSEA değeri 0.05 'ten küçükse iyi uyum, 0.05 ve 0.08 arasındaki bir değer aralığında ise yeterli uyum, 0.08 ile 0.10 arasında ise değerler orta/sıradan uyum olarak kabul edilebilir bir düzeydedir. Analiz sonucu elde edilen RMSEA değeri 0.065 yeterli bir uyum olduğunu göstermektedir. GFI ve AGFI değerleri, 0 ile 1 arasında kabul edilebilir bir değer almakta olup, 0.95 'e yakın değerler iyi uyumu yansitmaktadır (Schumacker ve Lomax, 2004: 82). Buna göre GFI (0.80) ve AGFI (0.76) değerleri kabul edilebilir uyum değerine sahiptir. NFI değerleri 0 ile 1 arasında değișir, NFI değeri 1'e yaklaştıkça daha iyi uyumu işaret etmektedir (Schermelleh-Engel., 2003: 40). NNFI değeri için 0.95'ten büyük değerler kabul edilebilir bir uyum olarak yorumlanabilirken, bu indeks için temel bir kural, 0.97 ile 1 aralığındaki değerlerin iyi uyumu göstermesidir (Schermelleh-Engel., 2003: 41). Analiz sonucunda elde edilen NFI ve NNFI değerleri iyi uyum değerine sahip olduğu görülmektedir. Bentler (1990)'a göre, bir model 1'e yakın bir CFI değerine sahipse model iyi uyum değerine sahiptir. CFI değerinin 0,98 olarak hesaplanması çalışmada ele alınan modelin iyi uyuma sahip olduğunu göstermektedir. SRMR değerinin 0.05 ile 0.10 aralığında olması kabul edilebilir bir uyum değerini göstermekte olup, 0 ile 0.05 arasındaki değerler ise iyi uyuma sahiptir (SchermellehEngel., 2003: 52). Çalıșmada elde edilen SRMR değerinin (0.054) kabul edilebilir bir uyuma sahip olduğu görülmektedir. İyi uyum için RMR değeri yaklaşık olarak 0.05 veya daha küçük bir değer olmalıdır (Evers vd., 2000: 225). Çalışmada elde edilen RMR değeri (0.05) iyi uyuma sahiptir.

Tablo 4'te araştırmanın hipotez sonuçları sunulmaktadır.

Tablo 4: Hipotez sonuçları tablosu

\begin{tabular}{|c|c|c|c|c|}
\hline Hipotezler & $\begin{array}{c}\text { Yol } \\
\text { katsayısı }\end{array}$ & $\mathbf{R}^{2}$ & $\begin{array}{c}\text { T- } \\
\text { değerleri }\end{array}$ & Sonuç \\
\hline $\begin{array}{l}\mathrm{H}_{1} \text { : Performans beklentisi } \\
\text { kullanım davranıșı }\end{array}$ & 0,81 & 0,66 & 10,62 & Desteklendi \\
\hline $\begin{array}{l}\mathrm{H}_{2} \text { : Çaba beklentisi } \\
\text { kullanım davranıșı }\end{array}$ & 0,87 & 0,76 & 10,54 & Desteklendi \\
\hline $\begin{array}{l}\mathrm{H}_{3} \text { : Sosyal etki } \cdot \\
\text { kullanım davranışı }\end{array}$ & 0,56 & 0,31 & 6,84 & Desteklendi \\
\hline $\begin{array}{l}\mathrm{H}_{4} \text { : Kolaylaștırıcı koșullar } \\
\text { kullanım davranıșı }\end{array}$ & 0,86 & 0,75 & 10,53 & Desteklendi \\
\hline $\begin{array}{l}\text { H5: Bilgi kalitesi - } \\
\text { kullanım davranışı }\end{array}$ & 0,91 & 0,83 & 10,89 & Desteklendi \\
\hline $\begin{array}{l}\mathrm{H}_{6} \text { : Sistem kalitesi - } \\
\text { kullanım davranıșı }\end{array}$ & 0,95 & 0,91 & 10,41 & Desteklendi \\
\hline $\begin{array}{l}\text { H7: Hizmet kalitesi - } \\
\text { kullanım davranıșı }\end{array}$ & 0,85 & 0,73 & 10,94 & Desteklendi \\
\hline $\begin{array}{l}\mathrm{H}_{8} \text { : Kullanım davranışı } \\
\text { kullanıcı tatmini }\end{array}$ & 0,90 & 0,81 & 11,24 & Desteklendi \\
\hline
\end{tabular}

Tablo 4 incelendiğinde yapısal eșitlik modeli analizinin sonuçlarına göre sistem kalitesi $(\beta=0.95, p<0.01)$ mobil ödeme hizmetleri kullanım davranışı üzerinde en fazla etkiye sahiptir ve kullanım davranışını $\left(\mathrm{R}^{2}=0,91\right) \% 91$ oranında açıklamaktadır. Sosyal etki $(\beta=0.56, p$ $<0.01$ ) mobil ödeme hizmetleri kullanım davranışı üzerinde en az etkiye sahiptir ve kullanım davranışını $\left(\mathrm{R}^{2}=0,31\right) \% 31$ oranında açıklamaktadır. Ayrıca kullanım davranışı kullanıcl tatmini üzerinde güçlü bir etkiye sahiptir ve $\left(R^{2}=0,81\right) \quad \% 81$ oranında açıklamaktadır.

\section{SONUÇ VE ÖNERÍLER}

Günümüzde özellikle gelişmiş ve gelişmekte olan ülkelerin nakitsiz bir topluma doğru yönelişi mobil ödemelere olan ilgiyi artırmaktadır. Ayrıca mobil ödemenin diğer geleneksel ödeme yöntemlere göre güçlü bir 
alternatif olmasina rağmen gereken kullanımının olmaması bu konuyu araştırmayı gerekli kılmaktadır. Mobil ödemelerin kullanıcılara sunduğu sayısız avantaj, araştırmacıları kullanıcıların mobil ödemeyi benimsemesi ya da kullanımına etki eden faktörleri araştırmaya teşvik etmektedir. $\mathrm{Bu}$ çalışmada, literatürde daha önce yapılan araştırmalardan farklı olarak UTUAT modeli ve IS Success modeli birleștirilerek bütünleşik bir model ile kullanıcıların mobil ödeme hizmetleri kullanım davranışı ve kullanıcı tatmini incelenmiştir. Bu nedenle çalışmanın literatüre katkı sağlayacağı düşünülmektedir.

Çalışmada elde edilen analiz sonuçlarına göre, sistem kalitesinin mobil ödeme hizmetleri kullanım davranışı üzerinde en fazla etkiye sahip boyut olduğu tespit edilmiştir. $\mathrm{Bu}$ çalışmadan elde edilen sonuçlara benzer şekilde, Dwived ve arkadaşları (2013) çalışmasında, sistem kalitesinin iyi bir düzeyde olmasının, söz konusu hizmetin kullanımını arttırdığını ve daha yüksek kullanıcı tatmini sağladığını ortaya koymaktadır. Zhou, (2013) çalışmasında, mobil ödeme hizmetleri bağlamında sistem kalitesini kullanıcı tatminini etkileyen temel faktör olarak bulmuştur. $\mathrm{Bu}$ nedenle hem işletme yöneticileri hem de mobil ödeme hizmet geliştiricileri, bireylerin mobil hizmet kullanım davranışı ve tatminini arttırmak için öncelikli olarak sistem kalitesini geliştirmek üzerine yoğunlaşmalıdır. $\mathrm{Bu}$ çalışmanın bir diğer önemli sonucu ise, sosyal etkinin mobil ödeme hizmetleri kullanım davranışı üzerinde en düşük etkiye sahip boyut olarak bulunmasıdır. Literatürdeki bazı çalışmalar (Bandyopadhyay ve Fraccastoro, 2007; Alshare ve A. A. Mousa 2011; Yang vd., 2012), mobil ödeme hizmetleri kapsamında sosyal etki boyutunun davranışsal niyet üzerinde güçlü bir etkisi olduğunu ortaya koymaktadır. Bu durum, bu çalışmadan elde edilen sonuçtan farklı yöndedir. Bunun bir sebebi olarak, çalışmada ele alınan örneklem grubunun, mobil ödeme hizmetleri kullanım davranıșına ilişkin bilgi ve beklentilerinin farklı yönde olmasından kaynaklı olduğu düşünülmektedir. Diğer bir ifade ile katılımcılar, mobil ödeme hizmetleri kullanım davranışında sosyal etkiden ziyade diğer boyutların daha önemli olduğu kanısındadırlar. $\mathrm{Bu}$ çalışmadan elde edilen sonuca benzer şekilde, Rosnidah ve arkadaşları (2019) çalışmasında, mobil ödeme hizmetleri kullanım davranışı üzerinde diğer çeşitli boyutlar arasında (performans beklentisi, çaba beklentisi vb.) sosyal etki boyutunu en düşük etkiye sahip boyut olarak bulmuşlardır.

Çalışmadan elde edilen bir diğer önemli sonuç ise, kullanım davranışının kullanıcı tatmini üzerinde güçlü bir etkiye sahip olması şeklindedir. Mobil ödeme hizmetleri geliştiricileri veya ilgili alan yöneticileri temel olarak mobil ödeme hizmeti kullanımının bireyler arasında verimli bir şekilde nasıl arttırılacağı ile ilgilenmektedir. Bu çalışmada, mobil ödeme hizmetleri kullanım davranışında en çok etkiye sahip olarak belirtilen beş faktör (sistem kalitesi, bilgi kalitesi, çaba beklentisi, kolaylaştırıcı koşullar ve hizmet kalitesi), bireylerin mobil ödeme hizmetleri kullanım davranışını güçlendirmeye çalışan karar sahipleri için bir kılavuz görevi görebilir. Elde edilen bulgulara yönelik olarak, işletmelerin mobil ödeme hizmetlerinin kullanımına ve güvenilirliğine ilişkin bilgileri açık ve anlaşılır bir şekilde ortaya koyması, tüketicilerin mobil ödeme hizmetlerine ilişkin kullanım davranışı ve tatmini üzerinde etkili olacağı düşünülmektedir.

İşletmeler için mobil ödeme hizmetlerini kullanmanın birçok avantajı vardır bunlardan en önemlisi tüketicilerin ödeme işlemlerini kolaylaştırmasıdır. Mobil ödeme hizmetleri ile nakit, kredi kartı vb. araçlar yerine temassız kolay bir şekilde ödemeler desteklenmektedir. Benzer şekilde içinde bulunduğumuz COVID-19 sürecinde tüketiciler tarafından mobil ödeme hizmetlerine olan talep ve ilginin oldukça arttığı görülmektedir. İște bu noktada hem işletmeler hem de tüketiciler açısından mobil ödeme hizmetlerinin, ödeme işlemlerini kolaylaştırmasının önemi tekrar gündeme gelmiştir. Mobil ödeme hizmetlerinin işletmelere sağladı̆̆ 


\section{E. DURUKAL - K. ARMAN}

ödeme işlemlerine ilişkin makbuz vb. giderlerini ortadan kaldırarak ilgili dokümanların çeșitli yollar (örneğin, e-posta, kısa mesaj vb.) ile müșterilere gönderilmesini sağlamaktadır. Sürdürülebilirliğin öneminin her geçen gün önem kazandığı günümüz dünyasında ise işletmeler mobil ödeme hizmetlerinin bu yönü ile ekonomik ve çevresel sürdürülebilirliğe de katkı sağlamaktadır. Buna ek olarak, mobil ödeme hizmetleri tüketicilerin profilleri, satın alma davranışları ve satın alma sıklığı vb. açılardan işletmelere hızlı bir şekilde veri sağlarken, edinilen veriler müşteri hizmetleri yönetiminde de etkili olarak kullanılabilir. Tüketiciler açısından mobil ödeme hizmetleri kullanım davranışı incelendiğinde ise mobil ödeme hizmetlerinin kullanılması çeşitli araçların (internet, akıllı telefon, tablet vb.) ve teknolojik altyapı kullanılmasını gerekli kıldığı için özellikle gelişmekte olan ülkelerdeki tüketicilerin mobil ödeme hizmetleri davranışının güçlenmesinin zamanla artacağı düșünülmektedir. Bu çalışma mobil ödeme hizmetlerinde kullanıcı davranışı ve kullanıcı tatminine odaklanmaktadır. Mobil ödeme hizmetleri bağlamında literatürde daha önce yapılmış olan çalışmalardaki modeller arasında bu çalıșma, yeni bütünleșik bir model kullanmış olup, günümüzde BT içerisinde güncel ve önemli bir kavram olan mobil ödeme hizmetleri kavramının test edilmesine katkıda bulunmaktadır. Çalışmanın kısıtları, katılımcıların mobil ödeme hizmetini kullanan bireyler olması, kullanıcıların mobil ödeme hizmetlerine ilişkin belirli bir zamandaki düşüncelerini yansitıyor olması ve belirli bir örneklem ile sınırlı olmasıdır. Gelecekteki araştırmacılar, bu çalışmada yapılan bütünleștirilmiş UTAUT ve IS Success modelini, mobil ödeme hizmetleri üzerinde farklı örneklem grubu ve şehirler üzerinde ya da eödeme, m-devlet, m-alışveriş gibi farklı BT hizmetleri üzerinde test edip ortaya çıkan farklılıkları araștırabilir. Bununla birlikte, müşterilerin RFID teknolojisi, SMS, NFC ve QR vb. mobil ödeme sistemlerini ayrı ayrı ödeme aracı olarak benimsenmesini etkileyen faktörler karşılaștırılabilir. Ayrıca Starbucks, Walmart Pay gibi tek bir markayla bağlantılı, kapalı devre m-ödeme araçlarının benimsenmesi ve kullanımını etkileyen faktörlerin incelenmesi de gelecekteki araştırmalar için bir diğer öneridir.

\section{KAYNAKÇA}

Abrahão, R., S., Moriguchi, S., N., Andrade, D., F. (2016). Intention of Adoption of Mobile Payment: An Analysis in the Light of the Unified Theory of Acceptance and Use of Technology (UTAUT). RAI Revista de Administração e Inovação, 13, 221-230.

Adrian, B. (2002). Overview of The Mobile Payments Market 2002 through 2007. Gartner Research, R, 18-1818.

Al-Saedi, K., Al-Emran, M., Abusham, E., ve ElRahman, S. (2019). Mobile Payment Adoption: A Systematic Review of the UTAUT Model. 2019 International Conference on Fourth Industrial Revolution (ICFIR).

Alshare, K. A., Mousa, A. A. (2011). The Moderating Effect of Espoused Cultural Dimensions on Consumer's Intention to Use
Mobile Payment Devices. Proc. 35th Int. Conf. Inf. Syst., no. Zhou 2011, 1-15.

Aslam, W., Ham, M., Arif, I. (2017). Consumer Behavioral Intentions towards Mobile Payment Services: An Empirical Analysis in Pakistan. Market-Tržište, 29(2), 161-176.

Baabdullah, A. M., Alalwan, A. A., Rana, N. P., Kizgin, H., Patil, P. (2019). Consumer Use of Mobile Banking (M-Banking) in Saudi Arabia: Towards an Integrated Model. International Journal of Information Management, 44, 3852.

Bandyopadhyay, K., Fraccastoro, K. (2007). The Effect of Culture on User Acceptance of Information Technology. Commun. Assoc. Inf. Syst., 19, 522-543. 
Bentler, P. M. (1990). Comparative Fit Indexes in Structural Models. Psychological Bulletin, 107(2), 238.

Bentler, P., M., Yuan, K., H. (1999). Structural Equation Modeling with Small Samples: Test Statistics. Multivariate Behavioral Research, 34(2), 181-197.

Büyüköztürk, Ş. (2002). Faktör Analizi: Temel Kavramlar ve Ölçek Geliştirmede Kullanım. Kuram ve Uygulamada Eğitim Yönetimi Dergisi, 32, 470-483.

Byrne, B. (2009). Multivariate Applications Series. Structural Equation Modeling With AMOS: Basic Concepts, Applications, And Programming (2nd ed.). New York, NY, US: Routledge/Taylor \& Francis Group.

Chandra, S., Srivastava, S., Theng, Y.-L. (2010). Evaluating The Role of Trust in Consumer Adoption of Mobile Payment Systems: An Empirical Analysis. Communications of the Association for Information Systems, 27, 561588.

Comrey, A., Lee, H. (1992). A First Course in Factor Analysis, Hillsdale, NJ: Erlbaum.

Çokluk, Ö., Şekercioğlu, Ö. Büyüköztürk, Ş. (2010). Sosyal Bilimler İçin Çok Değişkenli İstatistik. Ankara: PEGEM Akademi.

Dahlberg, T. Mallat, N. Ondrus, J., Zmijewska, A. (2008). Past, Present And Future Of Mobile Payments Research: A Literature Review. Electronic Commerce Research and Applications 7 (2), 165-181.

Delone, W. H., Mclean, E. R. (1992). Information Systems Success: The Quest For The Dependent Variable. Information Systems Research, 3 (1), 60-95.

Delone, W. H., Mclean, E. R. (2003). The DeLone and Mclean Model Of Information Systems Success: A Ten-Year Update. Journal of Management Information Systems, 19(4), 930.

Dwivedi, Y. K., Kapoor, K. K., Williams, M. D., Ve Williams, J. (2013). Rfıd Systems in Libraries: an Empirical Examination of Factors Affecting
System Use And User

Satisfaction. International Journal of Information Management, 33(2), 367-377.

E-ticaret Raporu, (2019). http://www.tubisad.org.tr/tr/images/pdf/dd -tusiad-eticaret-raporu-2019.pdf, (28.1.2020).

Evers, A., Frese, M., Cooper, C. L. (2000). Revisions And Further Developments of The Occupational Stress Indicator: Lisrel Results From Four Dutch Studies. Journal of Occupational and Organizational Psychology, 73(2), 221-240

Hoe, S.L. (2008). Issues And Procedures in Adopting Structural Equation Modeling Technique. Journal of Applied Quantitative Methods, 3(1), 76-83.

Hongxia, P., Xianhao, X., Weidan, L. (2011). Drivers and Barriers in the Acceptance of Mobile Payment in China. International Conference on E-Business, sayfa aralığı yok.

Hooper, D., Coughlan, J., Mullen, M. R. (2008). Structural Equation Modelling: Guidelines for Determining Model Fit. The Electronic Journal of Business Research Methods, 6 (1), 53 - 60.

Joreskog, K. G. Sorbom, D. (1986). LISREL6 Computer Program. Moorseville, IN, Scientific Software.

Kalaycl, Ş. (2006). Spss Uygulamalı Çok Değișkenli İstatistik Teknikleri. Ankara, Turkey: Asil Yayın Dağıtım.

Kalinic, Z., Marinkovic, V., Molinillo, S., LiébanaCabanillas, F. (2019). A Multi-Analytical Approach To Peer-To-Peer Mobile Payment Acceptance Prediction. Journal Of Retailing And Consumer Services 49, 143-153.

Karnouskos, S., Fokus, F. (2004). Mobile Payment: A Journey Through Existing Procedures And Standardization Initiatives. Ieee Communications Surveys And Tutorials, 6(4), 44-66.

Khalilzadeh, J., Ozturk, A., B., Bilgihan, A. (2017). Security-Related Factors in Extended Utaut Model For NFC Based Mobile Payment in 
the Restaurant Industry. Computers in Human Behavior, 70, 460-474.

Kim, H. W., Xu, Y., Koh, J. (2004). A Comparison Of Online Trust Building Factors Between Potential Customers And Repeat Customers. Journal of The Association For Information Systems, 5(10), 13.

Kline, P. (1994). An Easy Guide To Factor Analysis:. New York: Routledge.

Koenig-Lewis, N., Marquet, M., Palmer, A., Zhao, A., L. (2015). Enjoyment And Social İnfluence: Predicting Mobile Payment Adoption. The Service Industries Journal, 35 (10), 537-554.

Kohli, R., Devaraj, S., Mahmood, M. A. (2004). Understanding Determinants of Online Consumer Satisfaction: A Decision Process Perspective. Journal of Management Information Systems, 21(1), 115-136.

Lee, J. W., Kwag, M. (2019). Structural Equation Modelling With Second-Order Confirmatory Factor Analysis: Critical Factors Influencing Consumer Behavior in Medical Tourism. In Quantitative Tourism Research İn Asia, (223-243). Springer, Singapore.

Luna, I. R. D., Liébana-Cabanillas, F., SánchezFernández, J., Muñoz-Leiva, F. (2018). Mobile Payment is not all the Same: The Adoption of Mobile Payment Systems Depending on The Technology Applied. Technological Forecasting and Social Change.

Mobil Ödeme Hizmetleri, (2015). https://www.btk.gov.tr/uploads/pages/slug/ mobil-odeme-hizmetleri.pdf, (30.1.2020).

Molina-Castillo, F., Lopez-Nicolas, C., Reuver, M. (2020). Mobile Payment: The Hiding Impact of Learning Costs on User Intentions. Journal of Theoretical and Applied Electronic Commerce Research, 15 (1), 1-12.

Mun, Y. P., Khalid, H., Nadarajah, D. (2017). Millennials' Perception on Mobile Payment Services in Malaysia. Procedia Computer Science, 124, 397-404.
Örs, M. E. (2018). Development of a Tehcnology Acceptance Odel For Mobile Payment Systems. The Middle East Technical University, Master Thesis.

Özdemir, A. (2013). Yönetim Biliminde İleri Araştırma Yöntemleri ve Uygulamalar. (3. Baskı Ed.): Beta Yayınevi.

Rennie, K.M. (1997). Exploratory And Confirmatory Rotation Strategies in Exploratory Factor Analysis. Paper Presented at the Annual Meeting of The Southwest Educational Research Association (Austin, January).

Roscoe, J. T. (1975). Fundamental Research Statistics for Behavioral Sciences. Holt, Rinehart and Winston, New York.

Rosnidah, I., Muna, A., Musyaffi, A., M., Siregar, N., F. (2019). Critical Factor of Mobile Payment Acceptance in Millenial Generation: Study on the UTAUT Model. Advances in Social Science, Education And Humanities Research, 306, 123-127.

Schermelleh-Engel, K., Moosbrugger, H., Müller, H. (2003). Evaluating The Fit of Structural Equation Models: Tests of Significance And Descriptive Goodness-Of-Fit Measures. Methods Of Psychological Research Online, 8(2), 23-74.

Schierz, P. G., Schilke, O., Wirtz, B. W. (2010). Understanding Consumer Acceptance of Mobile Payment Services: An Empirical Analysis. Electronic Commerce Research And Applications, 9(3), 209-216.

Schumacker, R. E., Lomax, R.G. (2004). A Beginner's Guide To Structural Equation Modeling (2nd Ed.). Mahlah, New Jersey, London: Lawrence Erlbaum Associates.

Schumacker, R.E., Lomax, R.G. (2010). A Beginner's Guide To Structural Equation Modeling. 3rd Ed., Routledge, New York, Ny.

Shamdasani, P., Mukherjee, A., Malhotra, N. (2008). Antecedents And Consequences of Service Quality in Consumer Evaluation of 
Self-Service Internet Technologies. Service Industries Journal, 28(1), 117-138.

Shankar, A., Datta, B. (2018). Factors Affecting Mobile Payment Adoption Intention: An Indian Perspective. Global Business Review, 19(3_Suppl), 72-89.

Shareef, M. A., Dwivedi, Y. K., Stamati, T., Williams, M. D. (2014). Sq Mgov: A Comprehensive Service-Quality Paradigm For Mobile Government. Information Systems Management, 31(2), 126-142.

Sharma, S.C. (1996). Applied Multivariate Techniques. John Wiley And Sons. New York.

Slade, E., Williams, M., Dwivedi, Y., Piercy, N. (2015). Exploring Consumer Adoption of Proximity Mobile Payments. Journal of Strategic Marketing, 23(3), 209-223.

Soni, M., Jain, K., Kumar, B. (2019). Factors Affecting The Adoption of Fashion Mobile Shopping Applications. Journal of Global Fashion Marketing, 10(4), 358-376.

Stapleton, C.D. (1997). Basic Concepts And Procedures of Confirmatory Factor Analysis. Paper Presented at The Annual Meeting of The Southwest Educational Research Association (Austin, January).

Suhr, D. (2006). Exploratory or Confirmatory Factor Analysis. Sas Users Group International Conference (1 - 17), Cary: Sas Institute, Inc.

Thakur, R., Srivastava, M. (2014). Adoption Readiness, Personal Innovativeness, Perceived Risk and Usage Intention Across Customer Groups For Mobile Payment Services in India. Internet Research, 24 (3), 369-392.

Türker, C. (2019). Tüketicilerin Yeni Teknolojiler Benimsemelerinin Teknoloji Kabul Modeli Boyutları İtibariyle İncelenmesi: Mobil Ödeme Sistemleri Üzerine Bir Araştırma. Yüksek Lisans Tezi, İstanbul Üniversitesi, İşletme Anabilim Dalı, İstanbul.

Venkatesh, V., Morris, M. G., Davis, G. B., Davis, F. D. (2003). User Acceptance of İnformation Technology: Toward a Unified View. Mis Quarterly, 27(3). 425-478.
Venkatesh, V., Thong, J., Xu, X. (2012). Consumer Acceptance And Use Of İnformation Technology: Extending The Unified Theory of Acceptance And Use of Technology. Mis Quarterly, 36(1), 157-178.

Verkijika, S., F. (2020). An Affective Response Model For Understanding the Acceptance of Mobile Payment Systems. Electronic Commerce Research And Applications, 39, 114.

Verma, S., Chaurasia, S., S., Singh, V. (2020). Understanding the Corpus of Mobile Payment Services Research: An Analysis of The Literature Using Co-Citation Analysis And Social Network Analysis. Journal of Information Systems and Technology Management -Jistem Usp V, 17,1-36.

Weston, R. Gore, P., A. (2006). A Brief Guide To Structural Equation Modeling. the Counselıng Psychologist, 34 (5), 719-751.

Yang, Q., Gong, X., Zhang, K.,Z., Liu, H., Lee, M.,K.,O. (2020). Self-Disclosure in Mobile Payment Applications: Common And Differential Effects of Personal and Proxy Control Enhancing Mechanisms. International Journal of Information Management, 1-20.

Yang, S., Lu, Y., Gupta, S., Cao, Y., Zhang, R. (2012). Mobile Payment Services Adoption Across Time: An Empirical Study of The Effects Of Behavioral Beliefs, Social Influences, And Personal Traits. Computers in Human Behavior, 28(1), 129-142.

Yang, Y., Liu, Y., Li, H., Yu, B. (2014). Understanding Perceived Risks in Mobile Payment Acceptance. Industrial Management \& Data Systems, 115 (2), 253-269.

Yaşlıoğlu, M. M. (2017). Sosyal Bilimlerde Faktör Analizi ve Geçerlilik: Keşfedici ve Doğrulayıcı Faktör Analizlerinin Kullanılması. İstanbul Üniversitesi İşletme Fakültesi Dergisi, 46, 74-85.

Yazıcıoğlu, Y., Erdoğan, S. (2004). Spss Uygulamalı Bilimsel Araştırma Yöntemleri. Detay Yayıncılık, Ankara. 


\section{E. DURUKAL - K. ARMAN}

Zhou, T. (2013). An Empirical Examination of Continuance Intention of Mobile Payment Services. Decision Support Systems, 54(2), 1085-1091. 